\title{
Holocene palaeosols and aeolian activities in the Umimmalissuaq valley, West Greenland
}

\author{
Müller, Michael ; Thiel, Christine; Kühn, Peter
}

Published in:

The Holocene

Link to article, DOI:

$10.1177 / 0959683616632885$

Publication date:

2016

Document Version

Peer reviewed version

Link back to DTU Orbit

Citation (APA):

Müller, M., Thiel, C., \& Kühn, P. (2016). Holocene palaeosols and aeolian activities in the Umimmalissuaq valley, West Greenland. The Holocene, 26(7), 1149-1161. https://doi.org/10.1177/0959683616632885

\section{General rights}

Copyright and moral rights for the publications made accessible in the public portal are retained by the authors and/or other copyright owners and it is a condition of accessing publications that users recognise and abide by the legal requirements associated with these rights.

- Users may download and print one copy of any publication from the public portal for the purpose of private study or research.

- You may not further distribute the material or use it for any profit-making activity or commercial gain

- You may freely distribute the URL identifying the publication in the public portal

If you believe that this document breaches copyright please contact us providing details, and we will remove access to the work immediately and investigate your claim 
The Holocene

\section{Holocene palaeosols and aeolian activities in the Umimmalissuaq valley, West Greenland}

\begin{tabular}{|c|c|}
\hline Journal: & The Holocene \\
\hline Manuscript ID & HOL-15-0126.R1 \\
\hline Manuscript Type: & Paper \\
\hline Date Submitted by the Author: & 15-Dec-2015 \\
\hline Complete List of Authors: & $\begin{array}{l}\text { Müller, Michael; University of Tübingen, Department of Geosciences, } \\
\text { Institute of Geography, Chair of Soil Science and Geomorphology } \\
\text { Thiel, Christine; Leibniz Institute for Applied Geophysics, Section 3: } \\
\text { Geochronology and Isotope Hydrology } \\
\text { Kühn, Peter; University of Tübingen, Department of Geosciences, Institute } \\
\text { of Geography, Chair of Soil Science and Geomorphology }\end{array}$ \\
\hline Keywords: & $\begin{array}{l}\text { Palaeosols, aeolian transport, grain size analysis, AMS radiocarbon dating, } \\
\text { deglaciation, Greenland, OSL dating }\end{array}$ \\
\hline Abstract: & $\begin{array}{l}\text { Aeolian sand sheets and active dunefields preserve an ancient Holocene } \\
\text { land surface represented by palaeosols that occur around the present ice } \\
\text { margin in the Kangerlussuaq area, West Greenland. To determine the } \\
\text { relation between Holocene aeolian activities and periods of soil formation, } \\
\text { both substantially dependent on the deglaciation history, palaeosols, } \\
\text { aeolian sand sheets, and dunefields were analysed using field data, grain } \\
\text { size analyses, optically stimulated luminescence dating and AMS }{ }^{14} \mathrm{C} \text { data in } \\
\text { an area of about } 15 \mathrm{~km}{ }^{2} \text { of the Ummimalissuaq valley. Located under } \\
\text { dunefields close to the ice margin ( }<2 \mathrm{~km}) \text {, palaeosols are developed in } \\
\text { fine-grained aeolian sediment (silt loam) and covered by sandy aeolian } \\
\text { layers. Silt contents of palaeosols of partly }>60 \text { wt. } \% \text { are comparable to } \\
\text { aeolian sand sheets currently formed at further distances ( } 4-5 \mathrm{~km} \text { ) from } \\
\text { the present ice margin. We propose a transport distance of fine aeolian } \\
\text { sediments, in which the palaeosols are formed, of at least } 4 \text { kilometres } \\
\text { from inboard of the present ice margin. Soil formation of the palaeosols } \\
\text { started around } 2700 \text { cal yr b2k. Datings from the youngest parts of the } \\
\text { palaeosols suggest a stable period of around } 2400 \text { years, which allowed for } \\
\text { pedogenesis and was characterised by low but constant aeolian activity. } \\
\text { Since aeolian activity intensified after around } 300 \text { cal yr b2k and developed } \\
\text { still active dunefields with coarse and medium sand accumulation, the ice } \\
\text { margin must have reached its present position since then. }\end{array}$ \\
\hline
\end{tabular}

\section{SCHOLARONE \\ Manuscripts}




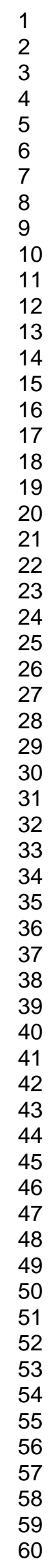

http://mc.manuscriptcentral.com/holocene 


\section{Holocene palaeosols and aeolian activities in the Umimmalissuaq valley, West}

\section{Greenland}

Michael Müller ${ }^{1}$, Christine Thiel ${ }^{2,3,4}$ and Peter Kühn ${ }^{1}$

$5 \quad{ }^{1}$ University of Tübingen, Department of Geoscience, Chair of Soil Science and

Geomorphology, Rümelinstrasse 19-23, D-72070 Tübingen, Germany

2 Leibniz Institute for Applied Geophysics, Section S3: Geochronology and Isotope Hydrology, Stilleweg 2, 30655 Hannover, Germany

3 Nordic Laboratory for Luminescence Dating, Department of Geosciences, Aarhus

10 University, Risø Campus, Frederiksborgvej 399, 4000 Roskilde, Denmark

${ }^{4}$ Centre for Nuclear Technologies (Nutech), Technical University of Denmark, Risø Campus, Frederiksborgvej 399, 4000 Roskilde, Denmark

\section{Corresponding author:}

15 Michael Müller, University of Tübingen, Department of Geoscience, Chair of Soil Science and Geomorphology, Rümelinstraße 19-23, D-72070 Tübingen, Germany

Email: michael.mueller@uni-tuebingen.de 
20 Abstract

Aeolian sand sheets and active dunefields preserve an ancient Holocene land surface represented by palaeosols that occur around the present ice margin in the Kangerlussuaq area, West Greenland. To determine the relation between Holocene aeolian activities and periods of soil formation, both substantially dependent on the deglaciation history, palaeosols, aeolian 25 sand sheets, and dunefields were analysed using field data, grain size analyses, optically stimulated luminescence dating and AMS ${ }^{14} \mathrm{C}$ data in an area of about $15 \mathrm{~km}^{2}$ of the Ummimalissuaq valley. Located under dunefields close to the ice margin $(<2 \mathrm{~km})$, palaeosols are developed in fine-grained aeolian sediment (silt loam) and covered by sandy aeolian layers. Silt contents of palaeosols of partly $>60 \mathrm{wt} . \%$ are comparable to aeolian sand sheets

30 currently formed at further distances $(4-5 \mathrm{~km})$ from the present ice margin. We propose a transport distance of fine aeolian sediments, in which the palaeosols are formed, of at least 4 kilometres from inboard of the present ice margin. Soil formation of the palaeosols started around 2700 cal yr b2k. Datings from the youngest parts of the palaeosols suggest a stable period of around 2400 years, which allowed for pedogenesis and was characterised by low but 35 constant aeolian activity. Since aeolian activity intensified after around $300 \mathrm{cal}$ yr b2k and developed still active dunefields with coarse and medium sand accumulation, the ice margin must have reached its present position since then.

\section{Keywords}

40 Palaeosols, aeolian transport, grain size analysis, AMS radiocarbon dating, OSL dating, deglaciation, Greenland 


\section{Introduction}

In general, areas close to the margins of ice sheets are strongly affected by aeolian activity (e.g. Dijkmans and Törnqvist, 1991; Willemse et al., 2003; French, 2007; Brookfield, 2011).

45 This is mainly due to strong katabatic winds associated with steep pressure gradients that develop at the margins of ice sheets (Schaetzl and Loope, 2008; Brookfield, 2011), where they reach their highest speeds (Dijkmans and Törnqvist, 1991).

The driving controls on most aeolian systems and particularly on sand sheet environments like in West Greenland are the source area, the availability of the source material, and wind

50 speed. The outwash-source zone for aeolian sand and silt is commonly controlled by variable discharge. In general, meltwater valleys near the margins of ice sheets are filled with silt-rich discharge in summer, and become dry and unprotected to aeolian erosion predominantly in winter (Schaetzl and Loope, 2008). Also, during winter with saltating snow and ice, aeolian mobility of sand is enhanced. The formation of a sand sheet either reflects adhesion to a

55 wetted surface or with vegetation (e.g. Koster and Dijkmans, 1988; Ruz and Allard, 1995). Often, the presence of snow and interstitial ice binds aeolian particles to surfaces necessitating higher threshold shear velocities for transport (Ollerhead et al., 2013), though the sublimation rate may be an important factor in grain release (Van Dijk and Law, 1995). The presence of snow ramparts and interstitial layers mostly composed of snow can enhance aeolian accretion

60 and dune movement (Koster and Dijkmans, 1988; Dijkmans and Mücher, 1989; Ruz and Allard, 1995). Further, aeolian transport and deposition of sand and silt is suggested to be affected and limited by topographical barriers (e.g. Mason et al., 1999; Mason, 2001).

Previous studies have shown a correlation between the distribution of wind-blown sediments and grain size, and the former extent of the ice sheet in West Greenland (e.g. Scholz and 65 Grottenthaler, 1988; Dijkmans and Törnqvist, 1991; Willemse et al., 2003). Driven by Holocene climatic fluctuations alternating phases of both soil formation and aeolian activity occurred with different intensities (e.g. Stäblein, 1975; Ten Brink, 1975; Weidick, 1985; 
Scholz and Grottenthaler, 1988; Dijkmans and Törnqvist, 1991; Van Tatenhove et al., 1996; Ozols, 2003; Willemse et al., 2003; Forman et al., 2007). The forefield of the inland ice 70 margin was affected by permanent modifications of the palaeoenvironment due to changing glacial dynamics, and alternating glaciofluvial and aeolian processes. These processes may be linked in complex manners; however the intensity of glaciofluvial and aeolian processes decreases with increasing distance from the ice margin (Dijkmans and Törnqvist, 1991; Schaetzl and Loope, 2008), and correspondingly the influence of wind on erosion and 75 sedimentation. Therefore, the changing distance from the ice margin to the outwash-source zone affected the variability in discharge, and thus the supply of aeolian sand and silt, which had impacts on the formation of soils, aeolian sand sheets and dunefields in the Holocene (cf. Willemse et al., 2003). Palaeosols developed in the aeolian sediments around Kangerlussuaq indicate an interruption or decrease of aeolian activity (e.g. Scholz and Grottenthaler, 1988;

80 Dijkmans and Törnqvist, 1991; Willemse et al., 2003). They can be taken as proxies for stable environmental conditions. For the timing of soil formation different data exist. According to Van Tatenhove et al. (1996) soil formation in Sandflugtdalen (Figure 1a) north of the study area started around $4560 \mathrm{cal}$ yr b2k. Willemse et al. (2003) assume an onset of soil formation prior to $3450 \mathrm{cal} \mathrm{yr}$ b2k and a halt in soil formation $600 \mathrm{cal} \mathrm{yr}$ b2k in Sandflugtdalen and 85 Ørkendalen (Figure 1a). Similarly, Dijkmans and Törnqvist (1991) suggest soil formation

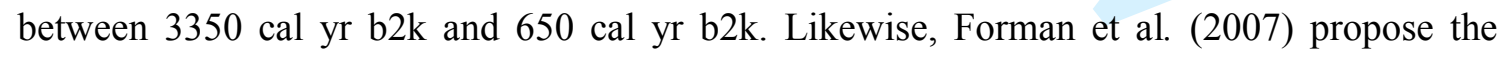
beginning of soil formation after 3 ka, whereas Ozols (2003, 1600 cal yr b2k) and Scholz and Grottenthaler $(1988,1.5 \mathrm{ka})$ assume a distinct later start. In general, soil formation around Kangerlussuaq has been strongly connected to dynamics of the inland ice: During a retreat of 90 ice, changing environmental conditions favoured soil formation in the study area due to lower discharge or more distal location from the source area, and thus lower intensity of katabatic winds and less supply of aeolian, whereas an advance led to an interruption of soil formation 
caused by opposite conditions. However, knowledge regarding the exact timing of soil formation in the Kangerlussuaq area is still insufficient, and more data are needed.

95 In this study, we aim to characterise the results of interaction of both aeolian-geomorphic processes and pedogenic processes across an E-W oriented valley in West Greenland. We further aim to understand how the intensity of these processes changed in response to middle and late Holocene glacial retreat and readvance. The lines of evidence include 1) the spatial patterns of modern landforms, surface sediments, and soils, and 2) the stratigraphy observed

100 along sampling transects, which allows for temporal reconstruction of these spatial patterns.

\section{Study area}

The Kangerlussuaq area is characterised by an E-W and ENE-WSW oriented valley system that leads the meltwater to the sea (Scholz and Grottenthaler, 1988). The E-W oriented 105 Umimmalissuaq valley is located in West Greenland, around 30 kilometres southeast of Kangerlussuaq (Figures 1a, b).

Figure 1. (a) (b)

110 The bedrock in the study area is mainly Precambrian gneiss (e.g. Scholz and Grottenthaler, 1988; Ozols and Broll, 2003; Henriksen, 2008); therefore the aeolian transported material consists of non-calcareous and non-basaltic material. Based on own field observations, the Ørkendalen glacier (Figure 1b) at the eastern side of the study area forms an active moraine system, which is overrunning current vegetation (Figure 2a). We observed the meltwater to

115 drain predominantly northward in the Ørkendalen valley, but also in the direction of the Umimmalissuaq valley. Forming a glacial outwash plain or sandur, and a delta, meltwater drains more or less directly into a lake system towards southwest and west, not using the Umimmalissuaq valley (Figures 1b, 2b). Compared to Sandflugtdalen or Ørkendalen, the 
outwash plain is small (ca. $0.2 \mathrm{~km}^{2}$ ). The entire outwash plain generally acts as source for 120 aeolian sediments. Own field observations indicated aeolian sand and silt to be mainly blown out from northwestern parts of the outwash plain (ca. 200-300 m southeast of profile D1, cf. Figure 1b), which are barely affected by meltwater channels in summer. Most parts of the valley itself are higher in elevation than the outwash plain (up to $50 \mathrm{~m}$ ). The study area further includes the hills north and south of the valley, which rise up to $150 \mathrm{~m}$ higher than the 125 outwash plain (Figures 1b, 2b).

The valley is covered by glacial deposits of the Keglen and Ørkendalen moraine systems as a result of the middle and late Holocene re-advances of the ice sheet (Stäblein, 1975; Ten Brink, 1975; Weidick, 1985). Moreover, glaciofluvial sediments are widespread in the valley. The glacial and glaciofluvial deposits, and most of the valley bottom and slopes are covered by a fine-grained aeolian sand sheet (ca. 60\% coverage, Figure 1b), apart from areas close to the ice margin (sandur, recent moraine, dunefields). North, northwest and west of the glacial outwash plain, there are still active coarse-grained dunefields (ca. $5 \%$ coverage; Figures $1 \mathrm{~b}$, 2b-d). Numerous distinct deflation areas cut into the aeolian sand sheet, and are present predominantly on top of moraines and slopes facing the ice margin (Figure 1b).

135

Figure 2. (a) (b) (c) (d)

The weather station closest to the study area is Kangerlussuaq Airport (Figure 1a). The present-day climate of Kangerlussuaq is Low Arctic continental: mean annual air temperature 140 is $-4.8^{\circ} \mathrm{C}$ and mean annual precipitation is $257 \mathrm{~mm}(1979-2008$; according to data from Boas and Wang, 2011). Low precipitation in winter (Cappelen, 2001) indicates a thin snow cover in the study area during winter months (Ozols and Broll, 2003). In Kangerlussuaq, mean wind speed at $2 \mathrm{~m}$ above ground level is $3.6 \mathrm{~m} / \mathrm{s}$ (1985-1999; Cappelen, 2001). Mean maximum wind speed at the same height is $19.6 \mathrm{~m} / \mathrm{s}$ (1985-1999; Cappelen, 2001), and most frequent 
145 wind direction is NE (Cappelen, 2001), indicating the effect of thermally induced katabatic winds and airflow channelling in the valleys (Van den Broeke and Gallée, 1996). The Umimmalissuaq valley is strongly affected by these katabatic winds which are stronger in winter due to a negative surface radiation and therefore a temperature deficiency above the snow-covered ablation zone (Willemse, 2000). Compared to Kangerlussuaq, the study area is

150 linked directly to the inland ice (Figures 1a, b). Thus, it is most probably drier and colder, and more affected by high wind speeds due to a stronger influence of katabatic winds from the inland ice, which can be assumed of being active also during the Holocene.

The topographic position, the distance from the ice margin and the aspect seem to be mainly responsible for the type of vegetative cover, the soil distribution, and the thickness of the 155 active layer of the permafrost in the study area. Permafrost exists at depths $<20-30 \mathrm{~cm}$ at north facing slopes, where organic-rich permafrost is common. At south facing slopes permafrost has not been detected $<1 \mathrm{~m}$. North facing (moist) slopes have dense vegetation and organic-rich soil horizons within the active layer, whereas south facing (dry) slopes or ridges have little or no vegetation and are thus subject to deflation.

160

\section{Materials and methods}

Mapping and sedimentary analysis

The geomorphological map (Figure 1b) is based on aerial photographs of the Danish Geodetic Institute (scale 1:40 000; Kort and Matrikelstyrelsen, 1968), publications from Scholz and

165 Grottenthaler (1988) and Ten Brink (1975), and own field surveys in 2009 and 2011.

In total 187 samples for grain size analysis (Supplementary material Table S1) were taken in dunefields north, northwest and west to the glacial outwash plain (Figures 1b, 2b-d), and in four cross-sections through the valley with different distances from the recent ice margin. Each cross-section comprises 9 resp. 10 sampling points; section 1 (sampling points 10-19) is 170 distal (ca. $4-5 \mathrm{~km}$ ) and section 4 (sampling points $40-48$ ) proximal (ca. 2-3 km) to the ice 
margin (Figure 1b). From each sampling point (10-48; Figure 1b) horizons at different depths were described according to the guideline for soil description (FAO, 2006) and subsequently sampled. At the cross-sections we refer to the upper $30 \mathrm{~cm}$ (maximum depth of active layer at north facing slopes) as the upper layer and to the horizons below $30 \mathrm{~cm}$ as the lower layer of

175 the aeolian sand sheet, respectively.

Additional buried humic palaeosols (lower layer) - found under still active dunes (soil profiles D0-D3, Figure 1b) - were sampled. For the upper layer (layer above the palaeosol as described more detailed in Results) a soil texture hand test was done in field to determine bands of different grain sizes. The grain size distribution of all samples was determined in the

180 laboratory after Blume et al. (2011) according to DIN ISO 11277.

Furthermore, depth, width, length, inclination, and aspect of 16 selected deflation areas (Supplementary material Table S2) were measured to get an overview where deflation is active and which kind of material is subject to wind erosion.

Statistical analyses for grain size distribution patterns were implemented with the free 185 programming language R, version 3.1.2 (R Development Core Team 2014) by applying Rpackages car (Fox and Weisberg, 2011), and RCMDR (Fox, 2005).

\section{Radiocarbon dating}

Soil organic matter from the palaeosols was dated by AMS ${ }^{14} \mathrm{C}$ dating in the laboratory of

190 Erlangen/Germany (abbr. Erl-; see Table 2). Calibration of ${ }^{14} \mathrm{C}$ data was done with OxCal 4.2 (Bronk Ramsey, 2009). Radiocarbon dating was performed on 14 samples after pre-treatment according to the acid-alkali-acid method: the samples were heated at $80^{\circ} \mathrm{C}$ in $1 \mathrm{M} \mathrm{HCl}$ to remove carbonates. Then, the samples were heated at $80^{\circ} \mathrm{C}$ in $1 \mathrm{M} \mathrm{NaOH}$ to remove humic acids and fulvic acids, respectively. Afterwards, the samples were heated at $80^{\circ} \mathrm{C}$ again in $1 \mathrm{M}$

$195 \mathrm{HCl}$ to remove remaining carbonates. Finally, the samples were dried at $100^{\circ} \mathrm{C}$, and stored in closed glasses to avoid contamination. Six samples were taken from varying depths in profile 
D1, and five samples from varying depths in profile D2 in the active dunefields (Figure 1b). Additionally, the soil organic matter of three palaesols of transects 1 to 3 were dated (profiles 17, 24, 33 in Figure 1b).

200

\section{Optically stimulated luminescence dating}

Four samples from profile D2 (sampling depths given in Table 3) were dated using both quartz and feldspar optically stimulated luminescence (OSL). Sand grains ranging from 90$180 \mu \mathrm{m}$ were obtained through wet-sieving the bulk sample (taken in opaque tubes), followed 205 by treatment with $10 \% \mathrm{HCl}$ and $10 \% \mathrm{H}_{2} \mathrm{O}_{2}$ and subsequent density separation using fast float (LST; potassium-rich feldspar $\rho<2.58 \mathrm{~g} \mathrm{~cm}^{-3}$, quartz $\rho>2.62 \mathrm{~g} \mathrm{~cm}^{-3}$ ). The mineral extracts were etched with $10 \%$ hydrofluoric acid (HF) for 30 minutes in case of feldspar, and with $40 \% \mathrm{HF}$ for one hour in case of quartz, respectively. After etching, the samples were treated with $30 \% \mathrm{HCl}$ in order to remove any fluorides which might have built during the treatment.

210 Finally, the samples were washed with distilled water and dried at $50^{\circ} \mathrm{C}$ prior to re-sieving. The purity of the quartz extracts was tested following Duller (2003). All samples were contaminated by feldspar, so the extracts were re-etched in $40 \% \mathrm{HF}$ for 40 minutes, washed and re-sieved. The subsequent purity test showed that the aggressive treatment would not entirely remove the feldspar contribution to the OSL signal; thus this had to be done 215 instrumentally.

The samples were measured using Risø TL/OSL readers (model DA-20; Thomsen et al. 2006) equipped with a calibrated ${ }^{90} \mathrm{Sr} /{ }^{90} \mathrm{Y}$ beta source and with both blue $(470 \mathrm{~nm})$ and infra-red (IR; $870 \mathrm{~nm}$ ) emitting diodes. The luminescence signals of the quartz extracts were detected through a Hoya U-340 filter. Due to the feldspar contamination, the quartz was measured 220 using a double single-aliquot regenerative (dSAR) protocol (Banerjee et al., 2001). To find suitable measurement settings, both a pre-heat plateau and thermal transfer were measured on sample 143080 (cf. Table 3) with preheat temperatures ranging from $160^{\circ} \mathrm{C}$ to $300^{\circ} \mathrm{C}$. The 
cut-heat temperature following a test dose of $\sim 5$ Gy was $20^{\circ} \mathrm{C}$ below the preheat temperature. For each setting three aliquots were used, and the mean equivalent dose (De) was calculated. 225 Based on the results (Supplementary material Figure S1), a pre-heat of $200^{\circ} \mathrm{C}$ (cut-heat $\left.180^{\circ} \mathrm{C}\right)$ was chosen. The pre-heat was followed by IR stimulation at $50^{\circ} \mathrm{C}(100 \mathrm{~s})$ and a subsequent blue stimulation at $125^{\circ} \mathrm{C}(40 \mathrm{~s})$. Each measurement cycle ended with a high temperature clean-out $\left(280^{\circ} \mathrm{C}\right)$ using blue LEDs $(40 \mathrm{~s})$. For each sample, $>30$ small aliquots (few tens of grains) were measured. The initial $0.2 \mathrm{~s}$ of the decay curve minus a background 230 from the subsequent $1 \mathrm{~s}$ was used for calculation. The OSL signals are dominated by the fast component (Supplementary material Figure S2); however, less than 1\% of the aliquots passed the rejection criteria (recycling ratio within $10 \%$, test dose error within $20 \%$, signal more than 3 sigma above background). It was therefore decided to not continue the quartz measurements but test the feldspar extracts instead.

235 For equivalent dose measurements of the potassium-rich feldspar extracts, a single aliquot regenerative (SAR) procedure was employed (Wallinga et al., 2000) on small aliquots (few tens of grains). IR stimulation was carried out at $50^{\circ} \mathrm{C}$ for $100 \mathrm{~s}$ after preheating at $250^{\circ} \mathrm{C}(60$ $\mathrm{s})$; the response to the test dose of 2.5 Gy was measured in the same matter, followed by an IR clean-out at $280^{\circ} \mathrm{C}$. The luminescence signal was detected through a Schott BG39/Corning 7-

24059 filter combination. For each sample, twelve aliquots were measured, and the mean De was calculated. The signal collected during the initial $1.6 \mathrm{~s}$ of stimulation minus a background from the last $40 \mathrm{~s}$ was used for calculation. All aliquots passed the rejection criteria (recycling ratio within $10 \%$, test dose error within $10 \%$, signal more than 3 sigma above background). Dose recovery tests were conducted in order to test whether a given dose (prior to any 245 heating) can be accurately recovered. Three aliquots per sample were bleached for 4 hours in a Hönle SOL2 and then given a dose of 16 Gy (test dose 2.5 Gy) prior to measurement. For all samples except 143080 , given doses of were recovered within $10 \%$ of unity, whilst for sample 143080 , the recovery was only within $20 \%$ of unity. 
As feldspar may suffer from anomalous fading (Wintle, 1973), which would result in an age

250 underestimate, the fading rate ( $g$-value) was measured on six aliquots per sample following Auclair et al. (2003). The same settings as for De determinations were used, and both several prompt measurements and delays up to 10 hours were included. The fading correction is based on Huntley and Lamothe (2001).

In order to determine the dose rate, the radionuclides (Table 3) were measured using high-

255 resolution gamma-spectrometry (Murray et al., 1987). The radionuclide concentrations were converted into dose rates following Guérin et al. (2011), and the cosmic dose contribution was added (Prescott and Hutton, 1994).

\section{Results}

Aeolian deposits and landforms

Both small ( $<50 \mathrm{~cm}$ height) and large (up to $2 \mathrm{~m}$ height) longitudinal dunes established particularly in the transition zone from the glacial outwash plain to the dunefields (next to profile D1, Figure 1b). The areas between these vegetated longitudinal dunes have no 265 vegetative cover. In addition, dome-shaped and barchan-like dunes are present in the dunefields (Figure 2d); these become higher $(>2 \mathrm{~m})$ and larger with increasing distance from the glacial outwash plain. Aeolian sand ripples (e.g. Anderson, 1987; Yizhaq et al., 2004) are common both between and leeward of dunes, where steep sand ridges of several metres length and width were found: These sand ridges are characterised by the absence of vegetation 270 (Figures 2c, d).

The depths of the aeolian sand sheet (Figure 1b) strongly depend on topographical features and the distance from the ice margin. Greater depths of $50 \mathrm{~cm}$ or even $>100 \mathrm{~cm}$ (Table S1) are found on wind-protected sites, e.g. in depressions and on leeward sides of moraines. 
Deflation areas (Figure 1b) are widespread in the entire Umimmalissuaq valley and are

275 mainly present on S-SE facing slopes or on crests and S-SE facing parts of moraines (Table S2). These often oval-shaped aeolian blow-outs are characterised by sparse or absent vegetative cover, and cut deep into the aeolian sand sheet. Often the underlying moraine material or bedrock is exposed by wind erosion. The size of deflation areas ranges from a few to hundreds of metres in width and length, as well as their depth that ranges from around $1 \mathrm{~m}$ next to the present dunefields (e.g. deflation area 13; Table S2; Figure 1b) to around $30 \mathrm{~cm}$ with increasing distance from the ice margin (e.g. 7, 9; Table S2; Figure 1b).

\section{Sedimentary units and grain size distribution}

All soil profiles in the large dunefield (represented by D1-D3, Figure 1b) show alternating

285 sedimentary units of humus-free and humus-rich sediments. Buried humic palaeosols (Figure 3a: 1e-1g; Figure 3b: 2e-2h) can be taken as marker horizons dividing the profiles in an upper and a lower layer. The palaeosols are developed in the lower layer consisting mainly of fine sand and coarse silt (Figures 3a, b; for definition and contents of grain size fractions see Table S1). According to FAO (2006), the main texture of palaeosols is silt loam, sometimes sandy

290 loam. The morphology of palaeosols visible in Figures 3c and 3d is characterised by a continuous horizontal to subhorizontal alternating stratification of buried Ah and $\mathrm{C}$ horizons with aeolian sand and silt. The centimeter to decimeter thick darker bands (Ah horizons) indicate organic matter accumulation, which are separated by millimeter to centimeter thick lighter bands (C horizons) of same soil texture (mostly silt loam). These bands feature a nonhorizontal structure perturbed by cryoturbational processes (cf. Figures 3a-d). Palaeosols are covered by alternating bands (centimeter to decimeter) consisting of primarily coarse, medium and fine sand (upper layer; Figures 3a-d). The main texture in the upper layer is loamy coarse sand, but also sand is common, particularly in the uppermost bands. The clay content of $<5$ wt. $\%$ is negligible. In general, dune profiles show an abrupt decline in coarse 
300 and medium sand and an increase in fine sand and silt content at the transition from upper to lower layer (Figures 3a, b), reaching up to 64 wt.\% silt in profile D3.

Figure 3. (a) (b) (c) (d)

305 The main texture of the aeolian sand sheet (Figure 1b), represented by cross-sections 1 to 4 , is silt loam: silt and sand contents range between 25 and 75 wt.\% (Table S1). The lower layer of the aeolian sand sheet reaches partly close to $100 \%$ sand (Figures $4 a$, d). Clay content with a mean of 4 wt. $\%$ is negligible.

The majority of sampling points from cross-sections 1 to 3 show finer grain sizes in the upper

310 layer (mostly silt loam; Table 1, Figures 4b, d) and coarser grain sizes in the lower layer (mostly sandy loam, partly sand; Table 1, Figures 4a, d), whereas cross-section 4 is still more affected by coarser grain sizes in the upper layer (partly loamy coarse sand; Table 1, Figures $4 \mathrm{~b}, \mathrm{~d})$. Within each cross-section the variability of grain sizes is very heterogeneous and is greater than between the respective cross-sections. Hereby, the variability of grain sizes in the

315 upper layer of the cross-sections is distinctly lower and more homogeneous compared to the lower layer (Table 1, Figure 4d).

Table 1.

320 In general, sand contents significantly decrease with increasing distance from the ice margin (Pearson $r=-0.29, p<0.001)$, whereas silt contents increase $(r=0.27, p<0.001)$. This is even more pronounced in the upper layers of dune profiles and sampling points (sand: $r=-$ $0.69, \mathrm{p}<0.001 ;$ silt: $\mathrm{r}=0.68, \mathrm{p}<0.001 ;$ Figure $4 \mathrm{e})$. However, the lower layers do not show a significant decline in grain sizes with increasing distance from the ice margin (sand: $r=0.09$, 325 $\mathrm{p}=0.40 ;$ silt: $\mathrm{r}=-0.13, \mathrm{p}=0.25 ;$ Figures $4 \mathrm{a}, \mathrm{d})$. 
Grain sizes in the lower layer of dune sediments (palaeosols) are similar to grain sizes in the upper layer of cross-sections (texture: silt loam; Figures 4c, d; Table 1). A Levene test revealed variance homogeneity between palaeosols (lower layer) and the upper layers of cross-sections 1 to $4(\mathrm{~F}=0.23, \mathrm{p}=0.92)$. Using ANOVA $(\mathrm{F}=1.51, \mathrm{p}=0.20)$ and following Post-hoc Tukey test, we found no significant differences between grain sizes of palaeosols and cross-section $1(\mathrm{p}=0.54)$, cross-section $2(\mathrm{p}=0.30)$, cross-section $3(\mathrm{p}=0.94)$, and cross-section $4(p=0.99)$. The grain sizes in upper layers of cross-sections 1 and 2 , and crosssections 3 and 4, respectively, are similar.

335 Figure 4. (a) (b) (c) (d) (e)

$A M S^{14} C$ ages

A summary of AMS ${ }^{14} \mathrm{C}$ ages is given in Table 2. Soil organic matter from the palaeosol of profile D1 (Figure 3a) was dated to 330-57 cal yr b2k at a depth of $85 \mathrm{~cm}$ (Erl-19002), to $340 \quad 1113-848 \mathrm{cal} \mathrm{yr} \mathrm{b2k}$ at $95 \mathrm{~cm}$ (Erl-16621), and to 2731-2209 cal yr b2k at $140 \mathrm{~cm}$ (Erl19003). The palaeosol of profile D2 (Figure 3b) yields ages of 110-92 cal yr b2k in $76 \mathrm{~cm}$ depth (Erl-16622), 2975-2795 cal yr b2k in $115 \mathrm{~cm}$ depth (Erl-16623), and 2749-2258 cal yr b2k in $140 \mathrm{~cm}$ depth (Erl-19004).

Samples taken from the cover sediments of the palaeosols and the transition zone between 345 cover sediments and palaeosols show very young and imprecise ages (Erl-16619, Erl-16620, Erl-16622, Erl-19002), caused by organic matter, which has been developed during the atomic age since 1945.

Additionally, soil organic matter of buried palaeosols within cross-sections 1 to 4 was analysed. Sampling point 17 (Figures $1 \mathrm{~b}, 5 \mathrm{a}$ ) reveals an AMS ${ }^{14} \mathrm{C}$ age of 5335-4919 cal yr 350 b2k (Erl-19000); this is so far the oldest age of soil organic matter from the valley bottom. A palaeosol from sampling point 33 (Figures $1 \mathrm{~b}, 5 \mathrm{c}$ ) has an AMS ${ }^{14} \mathrm{C}$ age of $4876-4499 \mathrm{cal} \mathrm{yr}$ 
b2k (Erl-16614). Soil organic matter from sampling point 24 (Figures $1 \mathrm{~b}, 5 \mathrm{~b}$ ) was $\mathrm{AMS}{ }^{14} \mathrm{C}$ dated to 2975-2800 cal yr b2k (Erl-19001).

355 Table 2.

\section{Luminescence ages}

The total dose rates to feldspar taken from profile D2 vary between $2.04 \pm 0.07 \mathrm{~Gy} / \mathrm{ka}$ (sample 143081; cf. Table 3) and $2.37 \pm 0.08 \mathrm{~Gy} / \mathrm{ka}$ (sample 143078). The equivalent doses

$360\left(D_{e}\right.$ values) are more variable: The largest $D_{e}$ of $12.8 \pm 0.8$ Gy was observed for sample 143079 (D2-53), and the smallest $(2.4 \pm 0.1 \mathrm{~Gy})$ for sample 143080). The IRSL ages given are all fading corrected; the $g$-values vary between $2.87 \pm 0.03 \%$ /decade (143080) and $3.81 \pm$ $0.17 \% /$ decade (143078). In palaeosol D2, the uppermost sample (20 cm depth) was dated to $2.2 \pm 0.1 \mathrm{ka}$, while the sample at a depth of $53 \mathrm{~cm}(143079)$ has an IRSL age of $7.3 \pm 0.6 \mathrm{ka}$.

365 Sample 143080, just $16 \mathrm{~cm}$ below sample 143079 , was dated to $1.4 \pm 0.1 \mathrm{ka}$, whilst the lowermost sample (143081) at a depth of $115 \mathrm{~cm}$ resulted in $3.7 \pm 0.2 \mathrm{ka}$.

It is apparent that age inversions are present, i.e. the upper horizons show older ages than the lower ones. A possible cause for this might be age overestimation of the upper layers due to incomplete luminescence signal re-setting while the grains were being transported. The higher sand content of these two samples implies a shorter distance to the ice margin, which can result in poorer signal re-setting (e.g. Alexanderson and Murray, 2012). Further, it is possible that the material was mainly transported during winter months; in this case the sand will not have seen much daylight prior to its deposition. However, it is also possible that the ages of the lower samples are erroneous (dose recovery of sample 143080 was poor). A greater set of 375 samples will be needed to investigate these issues in detail. Further, as the quartz OSL did not give any results to compare the IRSL ages with, we reject the OSL data for any further discussion but do point out that there is partial agreement with the AMS ${ }^{14} \mathrm{C}$ data (see below). 
Table 3.

380

Figure 5. (a) (b) (c)

\section{Discussion}

\section{Linking aeolian processes and palaeosols}

385 The main requirements for aeolian transport of sand and silt across the Umimmalissuaq valley are (i) sufficient supply of coarse-grained and fine-grained material from the glacial outwash plain and (ii) the frequently blowing katabatic winds combined with (iii) the peculiar arid climate conditions at the ice margin (cf. Bullard and Austin, 2011).

Coarse-grained material (predominantly medium sand and coarse sand, upper layer; Figures

$3903 \mathrm{a}, \mathrm{b}, 4 \mathrm{~b}$; Table S1) is deposited predominantly in the active dunefields (Figure 1b) north, northwest and west of the glacial outwash plain. Scholz and Grottenthaler (1988) propose that, with the exception of active dunefields, no recent accumulation of aeolian material takes place in the study area. However, dust clouds have been observed to rise up to several hundreds of meters in the study area during summer. Even ice-near areas are covered by a

395 thin layer of fine sand and silt after such events (cf. German, 1971; Willemse et al., 2003). This may also currently provide durable (if combined with rainfall) sedimentation of fine sand and silt (upper layer of cross-sections in Figures 4b, d, e) in most parts of the Umimmalissuaq valley. Most likely, these events are stronger in winter because of a higher wind drift potential during this time of the year (e.g. Willemse, 2000), and the outwash-source zone is dry and unprotected against aeolian erosion (Schaetzl and Loope, 2008).

Deflation areas are widespread in the study area (Figure 1b), also in active dunefields. These deflation areas occur in the older aeolian sand sheet consisting of fine material, and hereby predominantly on wind exposed S-SE slopes and moraines with depths up to $1 \mathrm{~m}$ and areas 
from a few up to hundreds of $\mathrm{m}^{2}$ (Table 5). Similarly, Dijkmans and Törnqvist (1991)

405 describe a SE-NW orientation of these often bowl-shaped or oval-shaped aeolian blow-outs, sometimes up to $1 \mathrm{~m}$ deep with diameters of up to several tens of meters (cf. French, 2007). These frequently occurring blow-outs imply reworking of previously deposited sand and silt by wind, and wind erosion as the prevailing aeolian process outside the dunefields.

Within the active dunefields 1-2 km from the ice margin (Figure 1b), humic palaeosols (lower

410 layer, consisting of silt loam, Figures $3 \mathrm{a}, \mathrm{b}$ ) are developed in older sand sheets and preserved by deposition of the dune sands above (upper layer, consisting of loamy sand, Figures 3a, b). Generally, (i) the proportion of finer grain sizes (clay, silt) in the dunefields with $<15$ wt.\% is very small, (ii) the underlying cumulic palaeosols with finer material have no layers with coarser material comparable to the overlying dunes. According to Ten Brink (1975) the

415 palaeosols are located within the Ørkendalen moraine system (Figure 1b). Hence, the lower layer, in which the palaeosols have formed, must have accumulated after the formation of the Ørkendalen moraines, since the lower layer is clearly not of glacial origin. At that time, the ice had disappeared and a decreasing influence of the strong and dry katabatic winds affected moisture conditions and thus the availability of sediments, soil formation and correspondingly vegetation in the valley. Further, the dominance of pedogenesis after the formation of the Ørkendalen moraines reflects a balance between pedogenesis and the sedimentation rate, i.e. the cumulic palaeosols (with grain sizes predominantly of fine sand and coarse silt, Figures 3a-d) of more than $60 \mathrm{~cm}$ thickness represent a phase with lower intensity of aeolian activity and synsedimentary pedogenesis. During that period of time, the sedimentation rate generally 425 and particularly of coarse-grained material (sand) decreased which favoured pedogenic processes. However, thin lighter layers between thicker organic rich layers within the buried Ah horizons suggest intermittent sedimentation events during soil formation. These observations indicate that there was an episodically easily available source of fine to medium sand in the source area, and quickly colonising sedges and other vascular plants in the 
430 sedimentation area. Thus, pedogenesis became more intense during periods with decreasing sedimentation rates and vice versa. It is important to notice that the soil formation after the formation of the Ørkendalen moraines does not reflect an on-off system of aeolian sedimentation. Instead, alternating periods of enhanced and weaker soil formation occurred depending on the sedimentation rate. Cryoturbation features in the palaeosols of show the soil

435 horizons of palaeosols D1 and D2 (Figures 3a-d) were partly subject to cryoturbation and alternating of frost-thaw processes during the period of soil formation. This has to be also taken into account when interpreting any dating ages.

Since the ages from the lower boundaries of the palaeosols above the permafrost date back to 2731-2209 cal yr b2k (D1, $140 \mathrm{~cm}$, Figure 3a) and 2749-2258 cal yr b2k (D2, $140 \mathrm{~cm}$, Figure

$4403 \mathrm{~b}$ ), and the ages of the upper parts of the palaeosols date back to 330-57 cal yr b2k (D1, 85 $\mathrm{cm}$, Figure 3a) and 110-92 cal yr b2k (D2, $76 \mathrm{~cm}$, Figure 3b), a period of at least 2400 years of relatively stable conditions related to pedogenesis is very likely. Interestingly, we found with $2975-2795 \mathrm{cal} \mathrm{yr}$ b2k in $115 \mathrm{~cm}$ of profile D2 an older age than in $140 \mathrm{~cm}$ (Figure $3 \mathrm{~b}$ ). This inversion of ages may reflect a rejuvenation effect, which is likely caused by an

445 accumulation of younger humic substances above the permafrost table. A reason for that may be also cryoturbation processes, which led to relocation of soil organic matter (Bockheim, 2007).

A sample from the oldest parts of a palaeosol in the Umimmalissuaq valley yielded a relatively young TL (Thermoluminescence) age indicating the onset of soil formation after the 450 Ørkendalen period around 1380-980 ka (Scholz and Grottenthaler, 1988). Even though little information is provided on the TL data, one has to assume an age underestimate as anomalous fading has not been taken into account at that time. Ages from palaeosols in Sandflugtdalen indicate a distinct earlier beginning of soil formation around 4680-4490 cal yr b2k (UtC-2034, Van Tatenhove et al., 1996). Our data for the start of soil formation are similar to 3869-3123 cal yr b2k (UtC-5624; Willemse et al., 2003), to 3442-3263 cal yr b2k (GrN-14655; Dijkmans 
and Törnqvist, 1991), and to 3.19-2.67 ka (UIC-1556) and 3.16-2.69 ka (UIC-1558; Forman et al., 2007; all from Sandflugtdalen and Ørkendalen, respectively). Two buried organic layers in Sandflugtdalen, which indicate the onset of soil formation, reveal younger ages of 19411236 cal $\mathrm{yr}$ b2k and 1866-1232 cal yr b2k (Ozols, 2003). The results from the 460 Umimmalissuaq valley indicate an earlier start of soil formation than discussed above. This may be confirmed in the future, since the base of the organic rich permafrost was not reached in profiles D1 and D2 in 2011. The lowermost AMS ${ }^{14} \mathrm{C}$ ages are from top of the permafrost table.

In the study area, aeolian activity intensified after around 300 cal yr b2k (Erl-16620, Erl-

465 19002, Table 2), and medium to coarse sand (Figures 3a, b) was transported from a nearby available source forming dunefields (upper layer), which cover the palaeosols in the foreland of the active ice margin. This suggests a markedly increasing sedimentation rate of coarsegrained material. Most likely, these processes have been caused by a close ice margin followed by stronger dry katabatic winds and changes in sediment supply when the formation 470 of the dunefields began. This would explain also the distinct coarser grain sizes compared to the lower layer. The more or less continuous redistribution (erosion and accumulation) of predominantly coarse-grained sand by intensive and prevailing aeolian activity in the area of the dunefields limited further soil formation since then. Despite landscape heterogeneity in the study area, only the outwash plain and the adjacent terminal moraines (ice-cored 475 moraines) can be the present sediment source (Figure 1b).

All these findings lead us to the assumption that the sedimentation of the coarse material in the dunefields is connected to an advancing ice margin and its sandur area (if present), representing the source of the coarse material. This means additionally that a period of time with predominant deposition of fine material is most likely related to a more easterly situated 480 ice margin, because the lacking of coarse material in the lower layer of dunefields. 
Compared to our results, a (re)accumulation of aeolian sand after the period of soil formation in Ørkendalen and Sandflugtdalen is assumed to have started earlier around 595-550 cal yr b2k (UtC-5619; Willemse et al., 2003), and 735-560 cal yr b2k (GrN-14651; Dijkmans and Törnqvist, 1991; for further data see Table 2). The different timings of the sedimentation of wind-blown coarser material could be interpreted related to the ice margin in the way, that the Late Holocene advance of the ice reached the present ice margin in the Umimmalissuaq valley later than in northerly adjacent valleys.

\section{Implications for the deglaciation history of the Umimmalissuaq valley}

490 The ice margin in West Greenland in general is assumed to have reached its present position already around $6000 \mathrm{yr} \mathrm{BP}$, followed by a minimum extent behind the present ice margin at around 4000 yr BP during the Holocene thermal maximum (Ten Brink and Weidick, 1974; Simpson et al., 2009). Since that time the ice sheet advanced again to its recent limits and further, resulting in younger moraine deposits (e.g. Ørkendalen, Figure 1b). Several different 495 data exist for the Ørkendalen moraine system in West Greenland: it has been dated to 700-300 BP (Ten Brink, 1975; UW-180, Table 2) and to 2.5-1.5 ka (Scholz and Grottenthaler, 1988). In great contrast, other studies date the Ørkendalen moraine system to $6.8 \pm 0.3 \mathrm{ka}$ by ${ }^{10} \mathrm{Be}$ (Levy et al., 2012) and to $6.8 \pm 0.3$ cal ka b2k (UtC-1987, UtC-1990; Van Tatenhove et al., 1996; Table 2).

500 In contrast, our AMS ${ }^{14} \mathrm{C}$ data from soil organic matter of the overlying palaeosols in the Umimmalissuaq valley yielded a minimum age of 2749-2258 cal yr b2k (Erl-19004, Table 2) for the Ørkendalen moraines, most likely even older (cf. 2975-2795 cal yr b2k, Erl-16623).

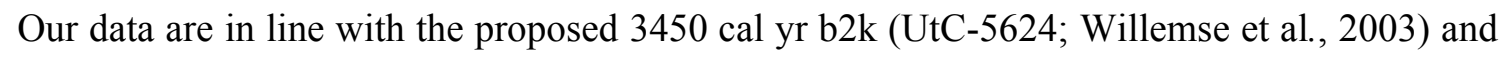
3350 cal yr b2k (GrN-14655; Dijkmans and Törnqvist, 1991) for the recession of the ice

505 margin in Sandflugtdalen and Ørkendalen. After development of the Ørkendalen moraines the inland ice melted again at its margin and retreated beyond its present limit. Previous studies 
proposed a former recession of the ice margin in West Greenland after formation of the Ørkendalen moraines of more than 10 kilometres (Weidick, 1985; Scholz and Grottenthaler, 1988), or even of 16 kilometres (Van Tatenhove et al., 1996). The changing distance from the

510 ice margin to the outwash-source zone after formation of the Ørkendalen moraines affected the formation of soils, aeolian sand sheets and dunefields in the study area (cf. Willemse et al., 2003). Since grain sizes decrease significantly with increasing distance from the ice margin (Figure 4e), and since grain sizes and their variability within the upper layer of crosssection 1 (silt contents: $54 \pm 6$ wt.\%; Table 1, Figures 4c, d) 4-5 km west of the present ice

515 margin are comparable to palaeosols covered by coarse-grained dunes (silt contents: $49 \pm 9$ wt.\%; Table 1, Figures 4c, d), we propose a transport distance of the fine aeolian sediments, in which the palaeosols have formed, of $<4$ kilometres from inboard of the present ice margin.

AMS ${ }^{14} \mathrm{C}$ ages of 5335-4919 cal yr b2k (sampling point 17), 4876-4499 cal yr b2k (33), and 520 2975-2800 cal yr b2k (24) (Figure 1b, Table 2) indicate soil formation also before 2749-2258 cal yr b2k (Erl-19004; Table 2). These palaeosols are situated between 4 and $5 \mathrm{~km}$ away from the present ice margin. All sampling points are located within the Umîvît/Keglen moraines (according to Ten Brink, 1975). This further implies a recession of the ice margin between the Umîvît/Keglen stage (with 7300 cal yr b2k, UtC-1987, UtC-1990, after Van Tatenhove et al., 525 1996, Table 2) and the Ørkendalen stage at least around 2700 cal yr b2k (Erl-19004; Table 2). As a consequence of lacking additional luminescence or ${ }^{10} \mathrm{Be}$ ages from the glacial sediments in the Umimmalissuaq valley the precise boundary between Umîvît/Keglen and Ørkendalen moraines is not clear.

\section{Conclusions}

During the Holocene the Umimmalissuaq valley has strongly been influenced by aeolian activities. This valley has a characteristic east-west orientation like numerous other valleys in 
West Greenland, and herewith the observed phenomena can be generally taken as representative for other valleys close to the ice margin in West Greenland.

535 Currently deflation - predominantly caused by easterly katabatic winds - redistributes aeolian sand sheets (silt loam) further west and forms active dunefields (consisting of loamy coarse sand and sand). Active dunefields occur particularly at south facing slopes north, northwest and west to the glacial outwash plain within around $2 \mathrm{~km}$ of the present ice margin. The data of grain size distribution, and $\mathrm{AMS}{ }^{14} \mathrm{C}$ data of the soils in the Umimmalissuaq valley lead to 540 the following findings:

1. Aeolian activity intensified after around $300 \mathrm{cal} \mathrm{yr}$ b2k and the still active dunefields with coarse and medium sand accumulation (upper layer) developed. Thus we infer the ice margin must have reached its present position around $300 \mathrm{cal} \mathrm{yr}$ b2k.

2. Palaeosols with humic A horizons located within the Ørkendalen moraine system are 545 developed in fine-grained aeolian sediment (silt loam - lower layer). They are covered by coarse-grained aeolian bands (loamy coarse sand to sand - upper layer). The lower layer, in which the palaeosols have formed, shows grain sizes comparable to aeolian sand sheets (upper layer), which are currently formed distal (in around $4 \mathrm{~km}$ distance) to the ice margin. Thus, we assume a transport distance of the fine aeolian sediments 550 of the lower layer - buried under the present dunefield next to the ice margin - of at least 4 kilometres from inboard of the present ice margin.

3. AMS ${ }^{14} \mathrm{C}$ dating of soil organic matter of these buried palaeosols yielded a minimum age of $2749-2258 \mathrm{cal} \mathrm{yr}$ b2k for the start of soil formation. Since traces of moraine material overlying the palaeosols could not be detected, this particular area must have been ice-free since that time. A potential earlier start of soil formation may be confirmed in the future, since the base of the organic rich permafrost was not achieved in profiles D1 and D2 in 2011. In contrast, the lowermost AMS ${ }^{14} \mathrm{C}$ ages from palaeosols buried under the dunefield are from top of the permafrost table. 
4. According to the youngest $\mathrm{AMS}{ }^{14} \mathrm{C}$ ages of the buried palaeosols a stable period of at least 2400 years can be inferred during the Late Holocene, in which the area was characterised by pedogenesis and low intensity of aeolian activity, but with constant input of fine sand and silt (lower layer).

\section{Acknowledgements}

565 This study was partly funded by DAAD (German Academic Exchange Service) and the Gesellschaft für Erd- und Völkerkunde in Stuttgart. The first author would also like to thank Christian Wolf and Jürgen Förth for their assistance during fieldwork and the great time in Greenland. The last author thanks all students helping in the field, and Frank Baumann, Joachim Eberle, Jessica Henkner, and Thomas Scholten for fruitful discussions.

\section{References}

Alexanderson H and Murray AS (2012) Luminescence signals from modern sediments in a glaciated bay, NW Svalbard. Quaternary Geochronology 10: 250-256.

Anderson RS (1987) A theoretical model for aeolian impact ripples. Sedimentology 34: 943575956.

Auclair M, Lamothe M and Huot S (2003) Measurement of anomalous fading for feldspar IRSL using SAR. Radiation Measurements 37: 487-492.

Banerjee D, Murray AS, Bøtter-Jensen L, Lang A (2001) Equivalent dose determination from a single aliquot of polymineral fine grains. Radiation Measurements 33: 73-94.

580 Blume HP, Stahr K and Leinweber P (2011) Bodenkundliches Praktikum: Eine Einführung in pedologisches Arbeiten für Ökologen, insbesondere Land-und Forstwirte, und für Geowissenschaftler. 3. Aufl.. Spektrum Akademischer Verlag, Heidelberg.

Boas L and Wang PR (2011) Weather and climate data from Greenland 1958-2010. Observation data with description. DMI Technical Report 11-15. Danish Meteorological 585 Institute. Copenhagen.

Bockheim JG (2007) Importance of cryoturbation in redistributing organic carbon in permafrost-affected soils. Soil Science Society of America Journal 71(4): 1335. doi:10.2136/sssaj2006.0414N.

Bronk Ramsey C (2009) Bayesian analysis of radiocarbon dates. Radiocarbon 51(1): 337 360 . 
Brookfield ME (2011) Aeolian processes and features in cool climates. In: Martini IP, French HM, Perez Alberti A (eds) Ice-marginal and Periglacial Processes and Sediments.

Geological Society, London, Special Publications 354: 241-258.

Bullard JE and Austin MJ (2011) Dust generation on a proglacial floodplain, West Greenland. Aeolian Research 3: 43-54.

Cappelen J, Jørgensen BV, Laursen EV, Stannius LS, Thomsen RS (2001) The Observed Climate of Greenland, 1958-99 - with Climatological Standard Normals, 1961-90. DMI Technical Report 00-18, Copenhagen.

Dijkmans JWA and Mücher HJ (1989) Niveo-aeolian sedimentation of loess and sand: an

600 experimental and micromorphological approach. Earth Surface Processes and Landforms 14: 303-315.

Dijkmans JWA (1990) Niveo-aeolian sedimentation and resulting sedimentary structures; søndre strømfjord area, Western Greenland. Permafrost Periglacial Processes 1: 83-96.

Dijkmans JWA and Törnqvist TE (1991) Modern periglacial eolian deposits and landforms in

605 the Søndre Strømfjord area, West Greenland and their palaeoenvironmental implications. Meddelelser øm Grønland, Geosciences 25: 1-39.

Duller GAT (2003) Distinguishing quartz and feldspar in single grain luminescence measurements. Radiation Measurements 37: 161-165.

Food and Agriculture Organisation of the United Nations (FAO), 2006. Guideline for soil 610 description. $4^{\text {th }}$ ed. Rome.

Forman SL, Marin L, Van der Veen C, Tremper C, Csatho B (2007) Little Ice Age and neoglacial landforms at the Inland Ice margin, Isunguata Sermia, Kangerlussuaq, west Greenland. Boreas 36: 341-351.

Fox J (2005) The R Commander: A basic-statistics graphical user interface to R. Journal of 615 Statistical Software 14(9): 1-42.

Fox J and Weisberg S (2011) An R companion to applied regression. $2^{\text {nd }}$ edition, Sage. 472 pp. URL: http://socserv.socsci.mcmaster.ca/jfox/Books/Companion

French HM (2007) The periglacial environment, third ed. John Wiley and Sons Ltd, Chichester.

620 German R (1971) Die wichtigsten Sedimente am Rande des Eises - ein aktuogeologischer Bericht von der Stirn des Kiagtutsermia bei Narssarssuaq (Süd-Grönland). N. Jb. Geol. Paläont. 138: 1-14.

Guérin G, Mercier N and Adamiec G (2011) Dose-rate conversion factors: update. Ancient TL 29 (1): 5-8.

625 Henriksen N (2008) Geological history of Greenland. Geological Survey of Denmark and Greenland (GEUS). Copenhagen.

Huntley DJ and Lamothe M (2001) Ubiquity of anomalous fading in K-feldspars and the measurement and correction for it in optical dating. Canadian Journal of Earth Sciences 38: $1093-1106$.

630 Kort and Matrikelstyrelsen (former Danish Geodetic Institute) (1968) Aerial images of Greenland. Copenhagen.

Koster EA and Dijkmans JWA (1988) Niveo-aeolian deposits and denivation forms, with special reference to the Great Kobuk sand dunes, Northwestern Alaska. Earth Surface Processes and Landforms 13: 153-170. 
635 Levy LB, Kelly MA, Howley JA, Virginia RA (2012) Age of the Ørkendalen moraines, Kangerlussuaq, Greenland: constraints on the extent of the southwestern margin of the Greenland Ice Sheet during the Holocene. Quat. Sci. Rev. 52: 1-5.

Mason JA (2001) Transport direction of Peoria loess in Nebraska and implications for loess source areas on the central Great Plains. Quaternary Research 56: 79-86.

640 Mason JA, Nater EA, Zanner CW, Bell JC (1999) A new model of topographic effects on the distribution of loess. Geomorphology 28: 223-236.

Murray AS, Marten R, Johnston A, Martin P (1987) Analysis for naturally occurring radionuclides at environmental concentrations by gamma spectrometry. Journal of Radioanalytical and Nuclear Chemistry 115: 263-288.

645 Ollerhead J, Davidson-Arnott R, Walker IJ, Matthew S (2013) Annual to decadal morphodynamics of the foredune system at Greenwich Dunes, Prince Edward Island, Canada. Earth Surface Processes and Landforms 38: 284-298.

Ozols U (2003) Bodenökologische Prozesse in permafrostbeeinflussten Böden Westgrönlands. Vergleich von Kobresia myosuroides-, Salix glauca- und Betula nana-

650 Beständen. Band 13, Arbeiten aus dem Institut für Landschaftsökologie Westfälische Wilhelms-Universität Münster.

Ozols U and Broll G (2003) Soil ecological processes in vegetation patches of well drained permafrost affected sites (Kangerlussuaq - Greenland). Polarforschung 73(1): 5-14.

Prescott JR and Hutton JT (1994) Cosmic ray contributions to dose rates for luminescence

655 and ESR dating: large depths and long-term variations. Radiation Measurements 23: 497-500.

R Development Core Team (2014) R: A language and environment for statistical computing.

R Foundation for Statistical Computing, Vienna, Austria. http://www.R-project.org/ (accessed 02 June 2015).

Ruz MH and Allard M (1995) Sedimentary structures of cold-climate coastal dunes, Eastern

660 Hudson Bay, Canada. Sedimentology 42: 725-734.

Schaetzl RJ and Loope WL (2008) Evidence for an aeolian origin for the silt-enriched soil mantles on the glaciated uplands of eastern Upper Michigan, USA. Geomorphology 100: 285295.

Scholz H and Grottenthaler W (1988) Beiträge zur jungholozänen Deglaziationsgeschichte im 665 mittleren Westgrönland. Polarforschung 58(1): 25-40.

Simpson MJR, Milne GA, Huybrechts P, Long AJ (2009) Calibrating a glaciological model of the Greenland ice sheet from the Last Glacial Maximum to present-day using field observations of relative sea level and ice extent. Quat. Sci. Rev. 28: 1631-1657.

Stäblein G (1975) Eisrandlagen und Küstenentwicklung in West-Grönland. Polarforschung 670 45(2): 71-86.

Storms JEA, de Winter IL, Overeem I, Drijkonigen GG, Lykke-Andersen H (2012) The Holocene sedimentary history of the Kangerlussuaq Fjord-valley fill, West Greenland. Quat. Sci. Rev. 35: 29-50.

Ten Brink NW (1975) Holocene history of the Greenland ice sheet based on radiocarbon-

675 dated moraines in West Greenland. Meddelelser øm Grønland 201(4): 1-44.

Ten Brink NW and Weidick A (1974) Greenland ice sheet history since the last glaciation. Quaternary Research 4: 429-440. 
Thomsen KJ, Bøtter-Jensen L, Denby PM, Moska P, Murray AS (2006) Developments in luminescence measurement techniques. Radiation Measurements 41: 768-773.

680 Van den Broeke MR and Gallée H (1996) Observation and simulation of barrier winds at the western margin of the Greenland ice sheet. Q. J. R. Meteorolog. Soc. 122: 1365-1383.

Van Dijk D and Law J (1995) Sublimation and aeolian sand movement from a frozen surface: experimental results from Presqu'ile Beach, Ontario. Geomorphology 11: 177-187.

Van Tatenhove FGM, Van der Meer JJM and Koster EA (1995) Implications for deglaciation 685 chronology from new AMS age determinations in Central West Greenland. Quat. Res. 45: 245-253.

Wallinga J, Murray A and Duller G (2000) Underestimation of equivalent dose in singlealiquot optical dating of feldspars caused by preheating. Radiation Measurements 32: 691695.

690 Weidick A (1985) Review of glacier changes in West Greenland. Z. Gletscherkd. Glazialgeol. 21: 301-309.

Willemse NW, Koster EA, Hoogakker B, Van Tatenhove FGM (2003) A continuous record of Holocene eolian activity in West Greenland. Quat. Res. 59: 322-334.

Willemse NW (2000) Arctic Natural Archives, lake and eolian sedimentary records from 695 West Greenland.Netherlands Geographical Studies 272. Utrecht.

Wintle AG (1973) Anomalous fading of thermoluminescence in mineral samples. Nature 245: 143-144.

Yizhaq H, Balmforth NJ and Provenzale A (2004) Blown by wind: nonlinear dynamics of aeolian sand ripples. Physica D 195: 207-228. 
Tables

Table 1. Variability of grain sizes (data shown in wt.\%) in dune sediments and the respective cross-sections; $\mathrm{SD}=$ standard deviation.

705

Table 2. AMS ${ }^{14} \mathrm{C}$ data and luminescence data of samples related to glacial, glaciofluvial and aeolian deposits in the Kangerlussuaq area, West Greenland, classified in the chronological context.

710 Table 3. Luminescence dating information, including radionuclide concentrations, water contents, dose rates (Dr), equivalent doses (De), g-values (i.e. fading rates) and (fading corrected) ages. Preference is given to the fading corrected ages. See text for details. $\mathrm{n}=$ number of aliquots measured to obtain average De's; s.e. $=$ standard error. 
715 Figures

Figure 1. (a) Map of the area around Kangerlussuaq, West Greenland showing the study area and the adjacent valleys Sandflugtdalen and Ørkendalen; modified after Storms et al., 2012. (b) Geomorphological map of the Umimmalissuaq valley based upon air-photo interpretation, 720 field evidence, and additional information in Ten Brink (1975).

Figure 2. (a) Recent moraine of Ørkendalen glacier overrunning current vegetation. Photo (2014) was taken towards northwest. (b) Umimmalissuaq valley with the glacial outwash plain and the large dunefield west/northwest of the outwash plain (for locations see Figure 1b)

725 - taken towards west/northwest. (c), (d) Large dunefield, glacial outwash plain and Ørkendalen glacier - (c) taken from profile D3 towards east, (d) taken from profile D2 towards east.

Figure 3. Dune profiles D1 and D2 (for location see Figure 1b) showing buried humic 730 palaeosols and overlying dune sands. (a), (b) Profile sketches of D1 and D2 with AMS ${ }^{14} \mathrm{C}$ data of soil organic matter, IRSL data, grain size distribution and pedology. For unmarked bands a soil texture hand test was done in field. The darker the palaeosol the higher the amount of soil organic matter. In both profiles permafrost was detected below $140 \mathrm{~cm}$. (c), (d) Photos of profiles D1 and D2 showing palaeosols (lower layer) and overlying dune sands 735 (upper layer). Traces of cryoturbation are present in both palaeosols.

Figure 4. (a), (b), (c) Soil texture ternary diagrams (data shown in wt.\%). (a) Lower layer of cross-sections 1 to 4 compared to lower layer of dunefields. Dune profiles show relatively fine, the sampling points from cross-section 1 to 4 partly coarse grain sizes. (b) Upper layer of 740 cross-sections 1 to 4 compared to the upper layer of dunefields. Highest sand contents, 
particularly in both coarse and medium sand range, were found in the dunefields. Crosssection 4 has higher contents of sandy loam compared to cross-sections 1 to 3 . (c) Lower layer of dunefields compared to the upper layer of cross-section 1. Note that grain sizes from the lower layer of dune profiles are in the same range as from the upper layer of cross-section

745 1. (d) Variability of sand content (wt.\%) in the upper layer (UL) and lower layer (LL) of dune sediments (Dunes) and cross-sections 1 to 4 (C1, C2, C3, C4). (e) Mean sand content (wt.\%) in the upper layer of dune sediments (filled dots) and cross-sections 1 to 4 (blank dots) with increasing distance $(\mathrm{m})$ from the ice margin.

750 Figure 5. Selected soil profiles from cross-sections showing grain size distribution, pedology and AMS ${ }^{14} \mathrm{C}$ data of soil organic matter. (a) Profile 17 (cross-section 1). (b) Profile 24 (crosssection 2). (c) Profile 33 (cross-section 3). For location of soil profiles see Figure 1b. 
Supplementary material

755

Table S1. Grain size analysis of all soil samples. Abbreviations and grain size fractions: cS = coarse sand $(0.63-2 \mathrm{~mm}), \mathrm{mS}=$ medium sand $(0.2-0.63 \mathrm{~mm}), \mathrm{fS} / \mathrm{ffS}=$ fine sand/very fine sand (fS: $0.125-0.2 \mathrm{~mm}$, ffS: $0.063-0.125 \mathrm{~mm}), \mathrm{cU}=$ coarse silt $(0.02-0.063 \mathrm{~mm}), \mathrm{mU}=$ medium silt $(0.0063-0.02 \mathrm{~mm}), \mathrm{fU}=$ fine silt $(0.002-0.0063 \mathrm{~mm})$, clay $(<0.002 \mathrm{~mm})$. For 760 location of soil profiles see Figure $1 \mathrm{~b}$.

Table S2. Investigated deflation areas illustrating measured aspects, inclinations, widths, lengths and depths. Description of aspect: $\mathrm{S}=$ South, $\mathrm{SE}=$ Southeast. The aspect and inclination are related to the hosting slope and moraine. The locations of the investigated deflation areas 765 are shown in Figure 1b with italic numbers.

Figure S1. OSL preheat plateau and thermal transfer for sample 143080. A preheat temperature of $200^{\circ} \mathrm{C}$ was chosen for the measurements.

770 Figure S2. a) Natural and b) regenerated (7 Gy) quartz OSL decay curve of one aliquot of sample 143079. The fast decay implies the presence of the fast component. 


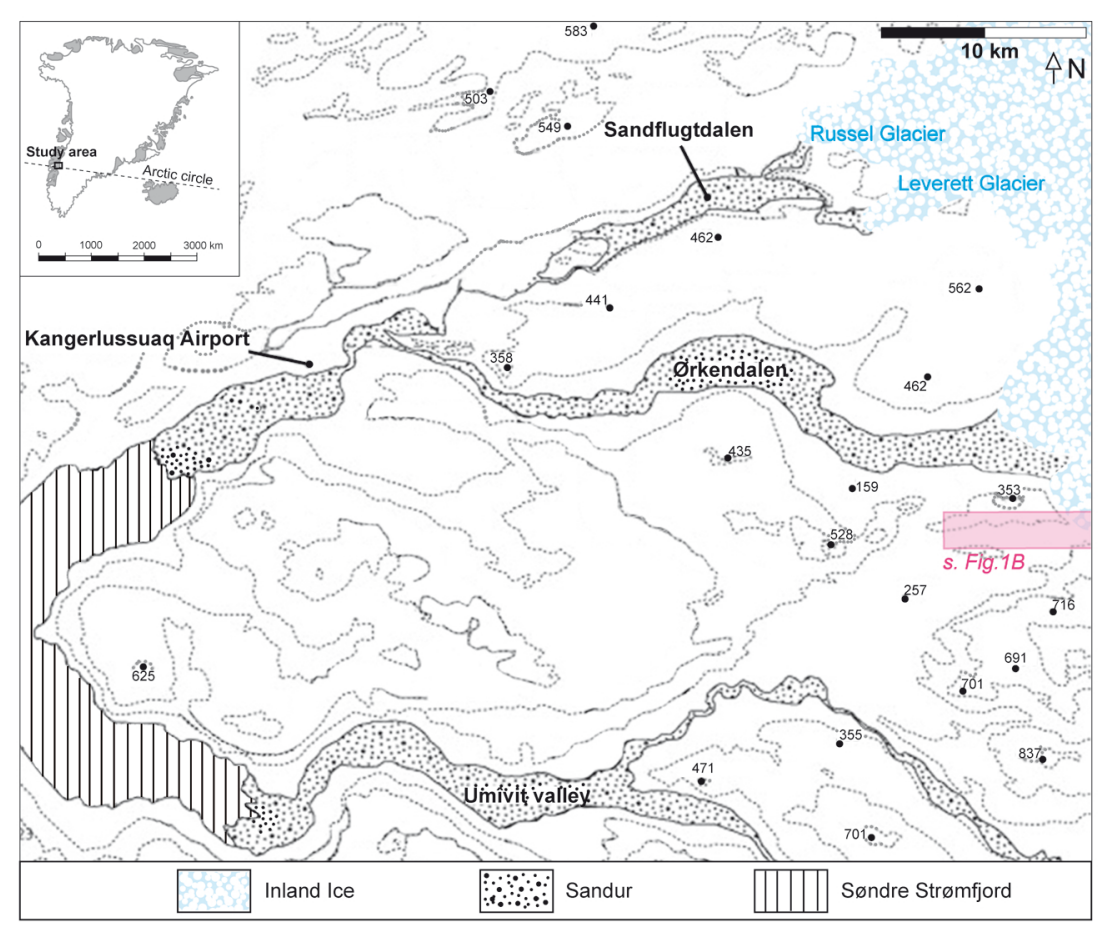




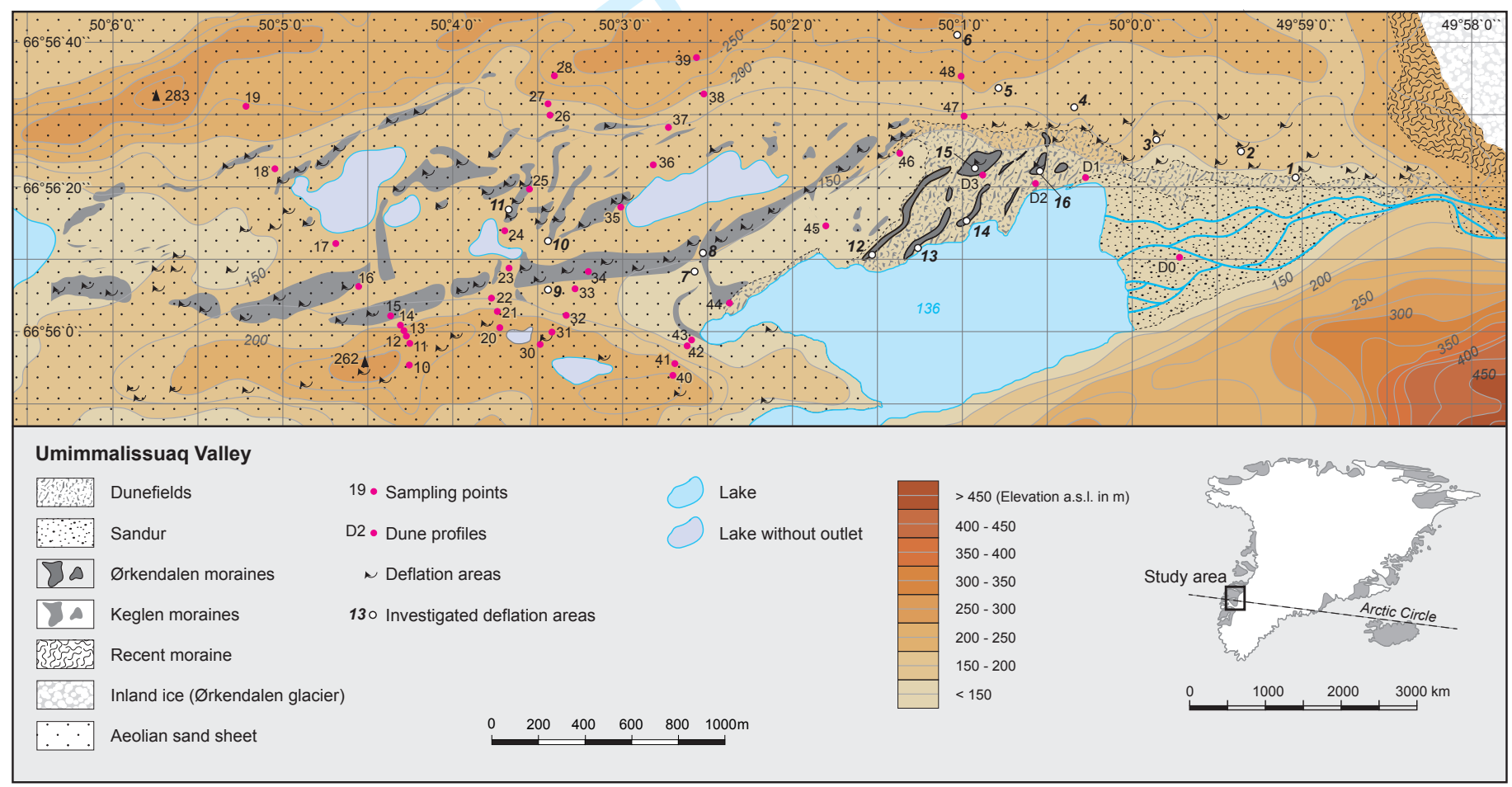




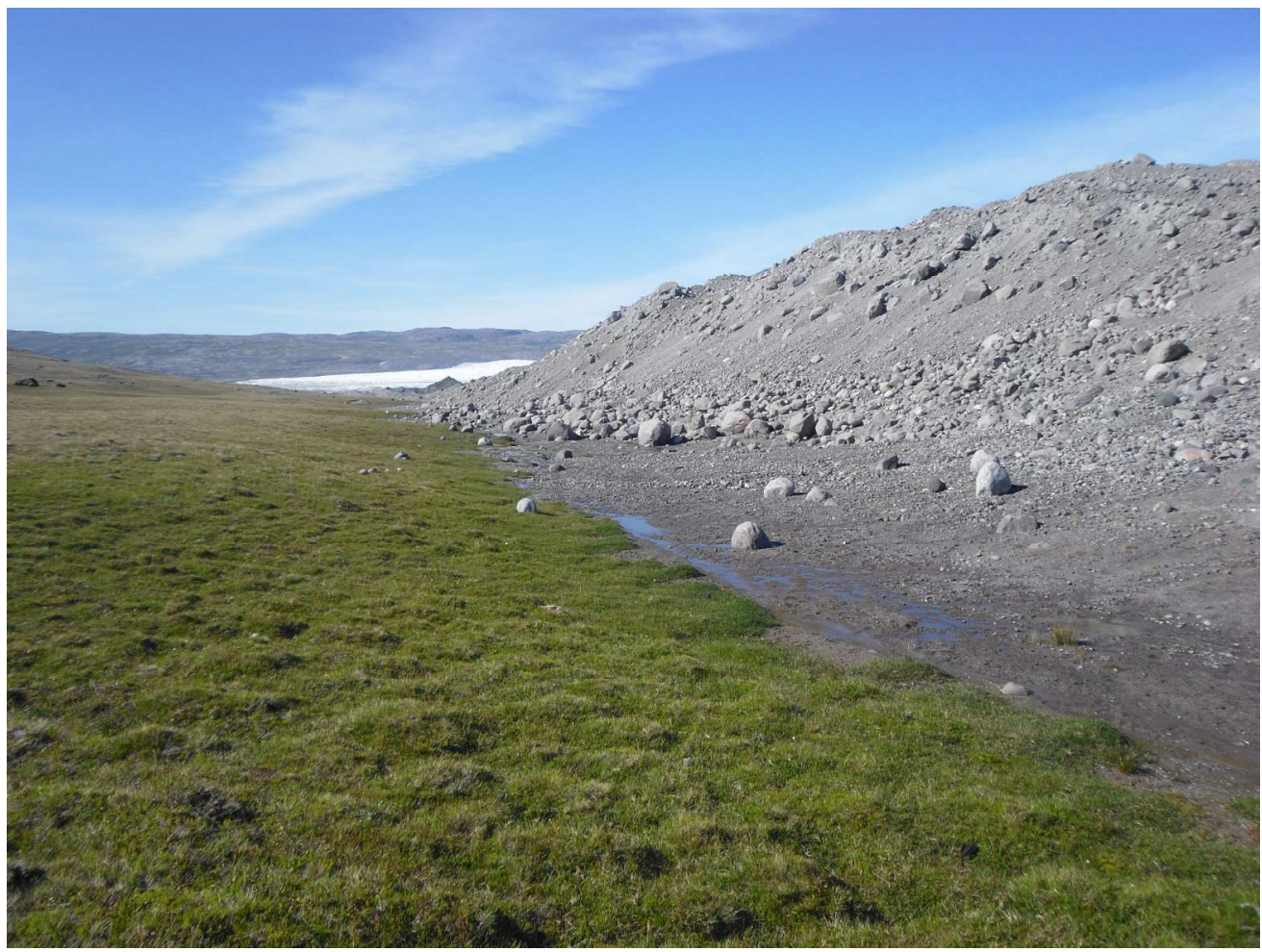

Figure 2. (a) Recent moraine of Ørkendalen glacier overrunning current vegetation. Photo (2014) was taken towards northwest. $812 \times 609 \mathrm{~mm}(72 \times 72 \mathrm{DPI})$ 


\section{Page 35 of 63}

\section{HOLOCENE}

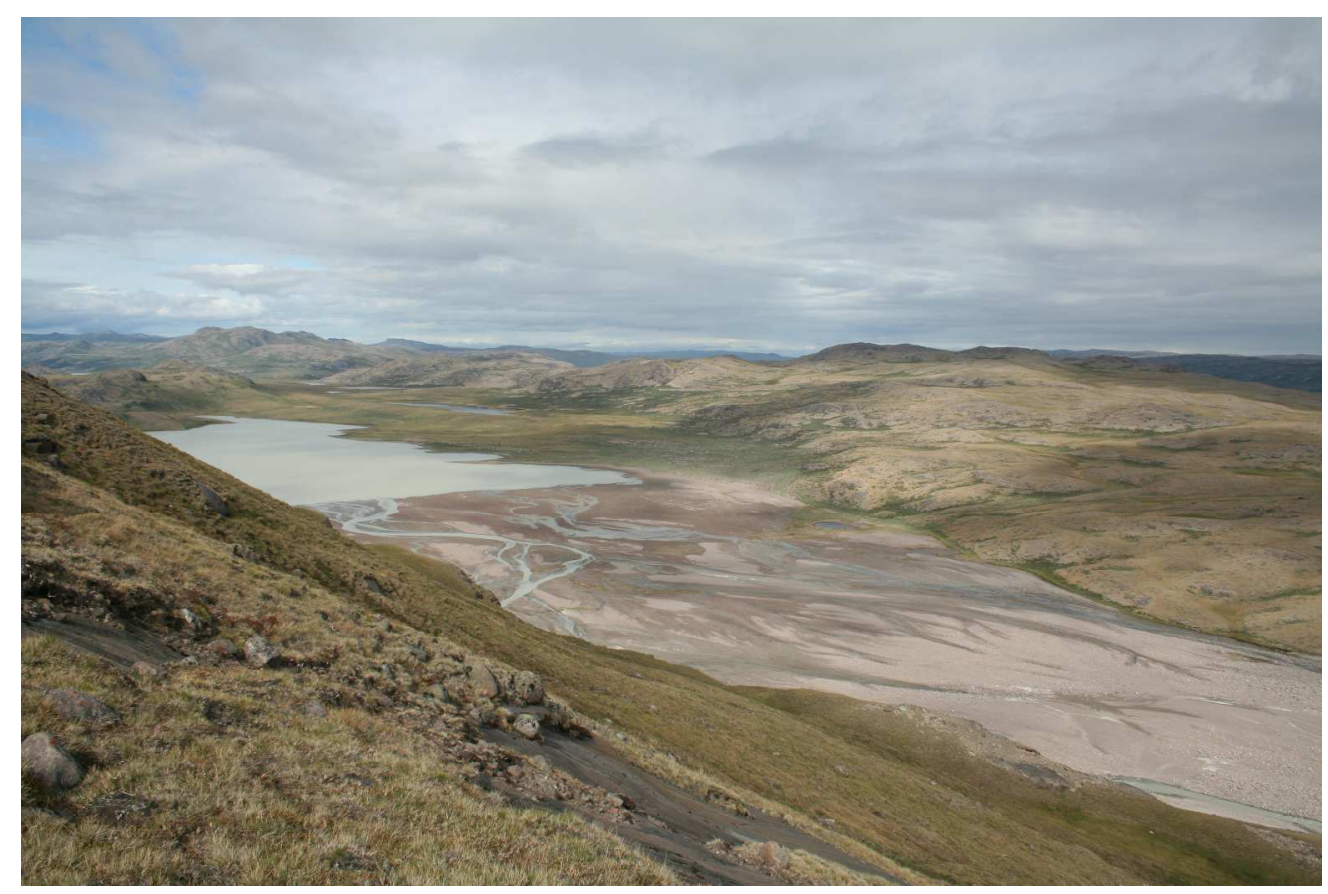

Figure 2. (b) Umimmalissuaq valley with the glacial outwash plain and the large dunefield west/northwest of the outwash plain (for locations see Figure 1b) - taken towards west/northwest. $1219 \times 812 \mathrm{~mm}(72 \times 72 \mathrm{DPI})$ 


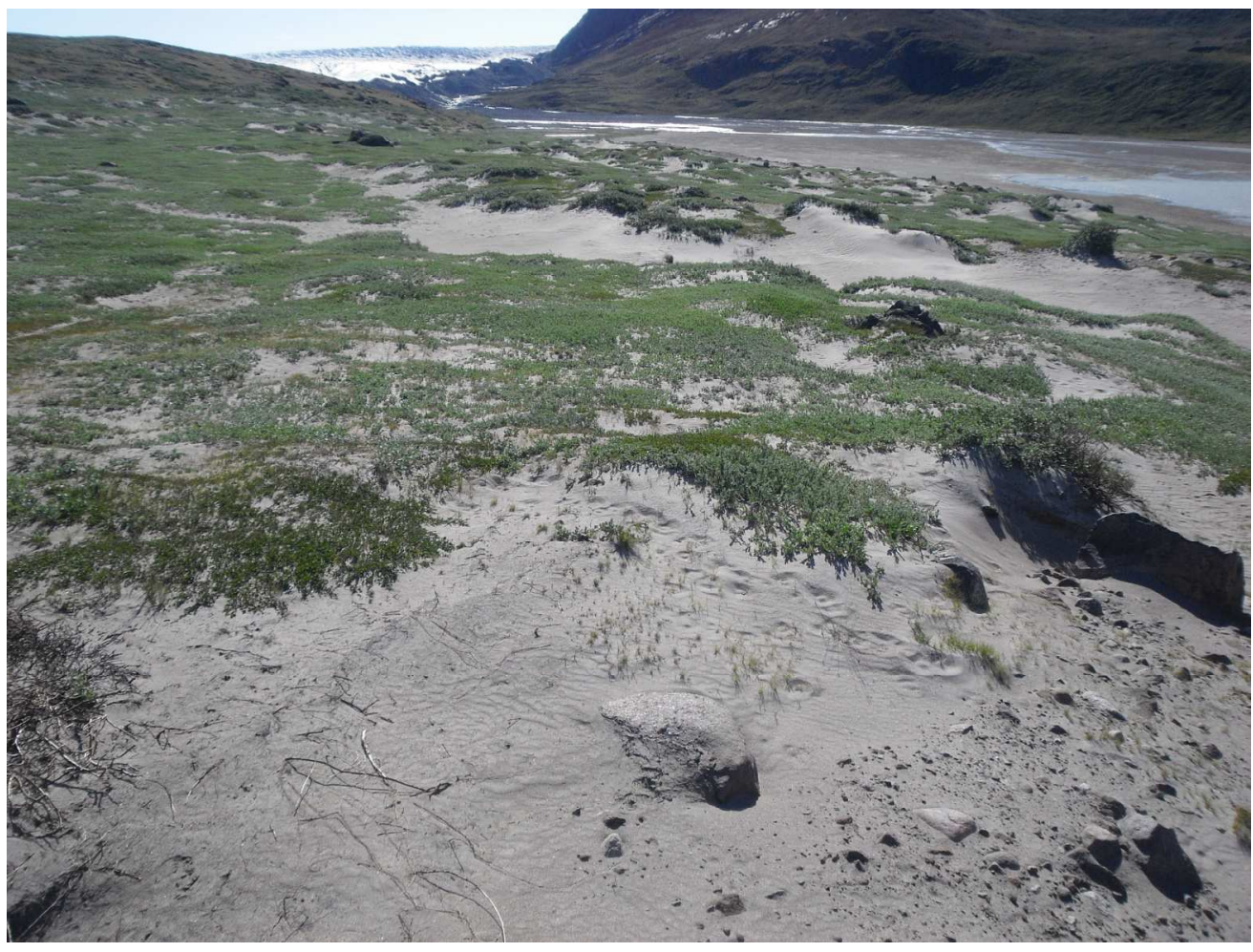

Figure 2. (c) Large dunefield, glacial outwash plain and Ørkendalen glacier - taken from profile D3 towards east.

$812 \times 609 \mathrm{~mm}(72 \times 72$ DPI $)$ 


\section{Page 37 of 63}

\section{HOLOCENE}

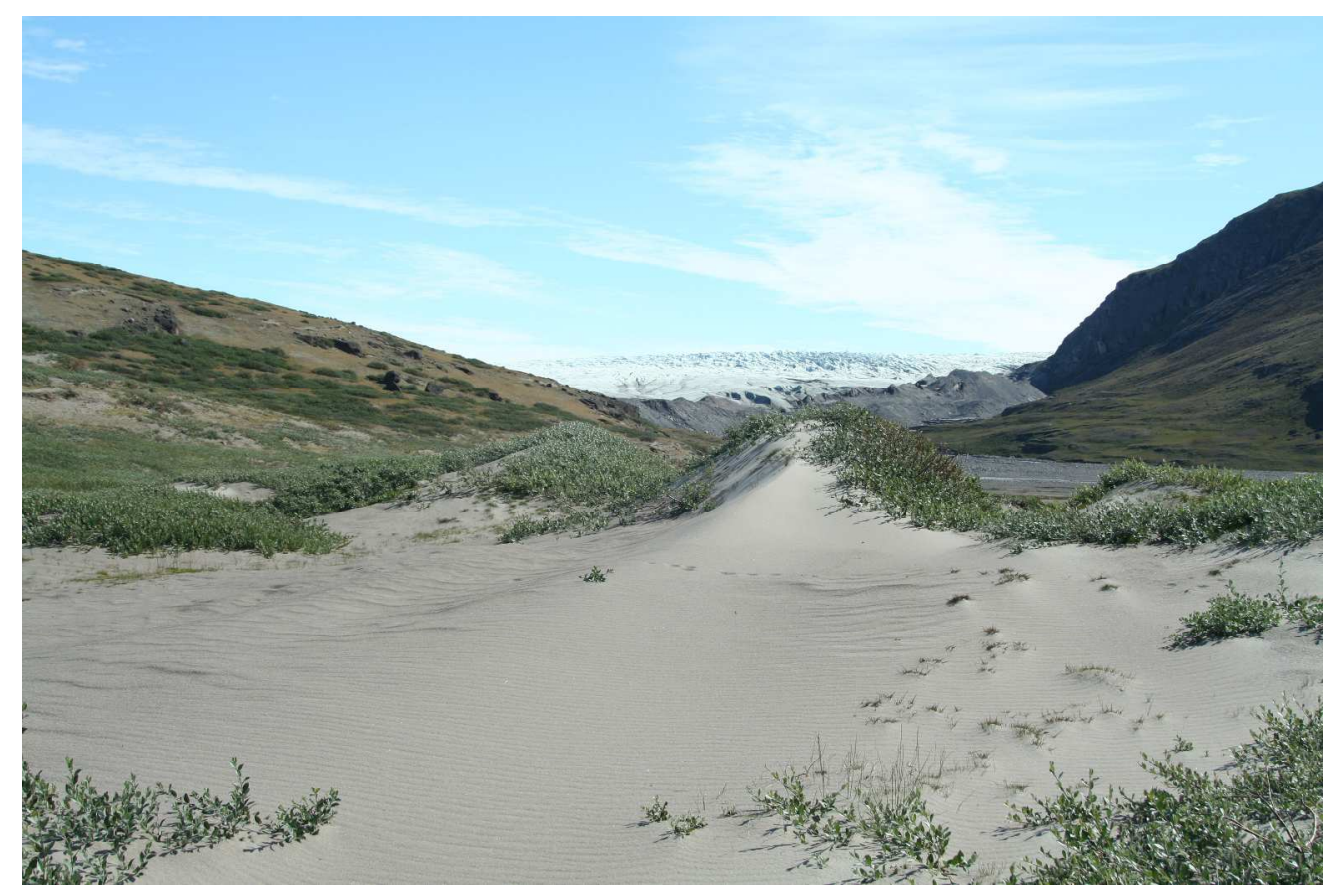

Figure 2. (d) Large dunefield, glacial outwash plain and Ørkendalen glacier - taken from profile D2 towards east.

$1219 \times 812 \mathrm{~mm}(72 \times 72$ DPI $)$ 


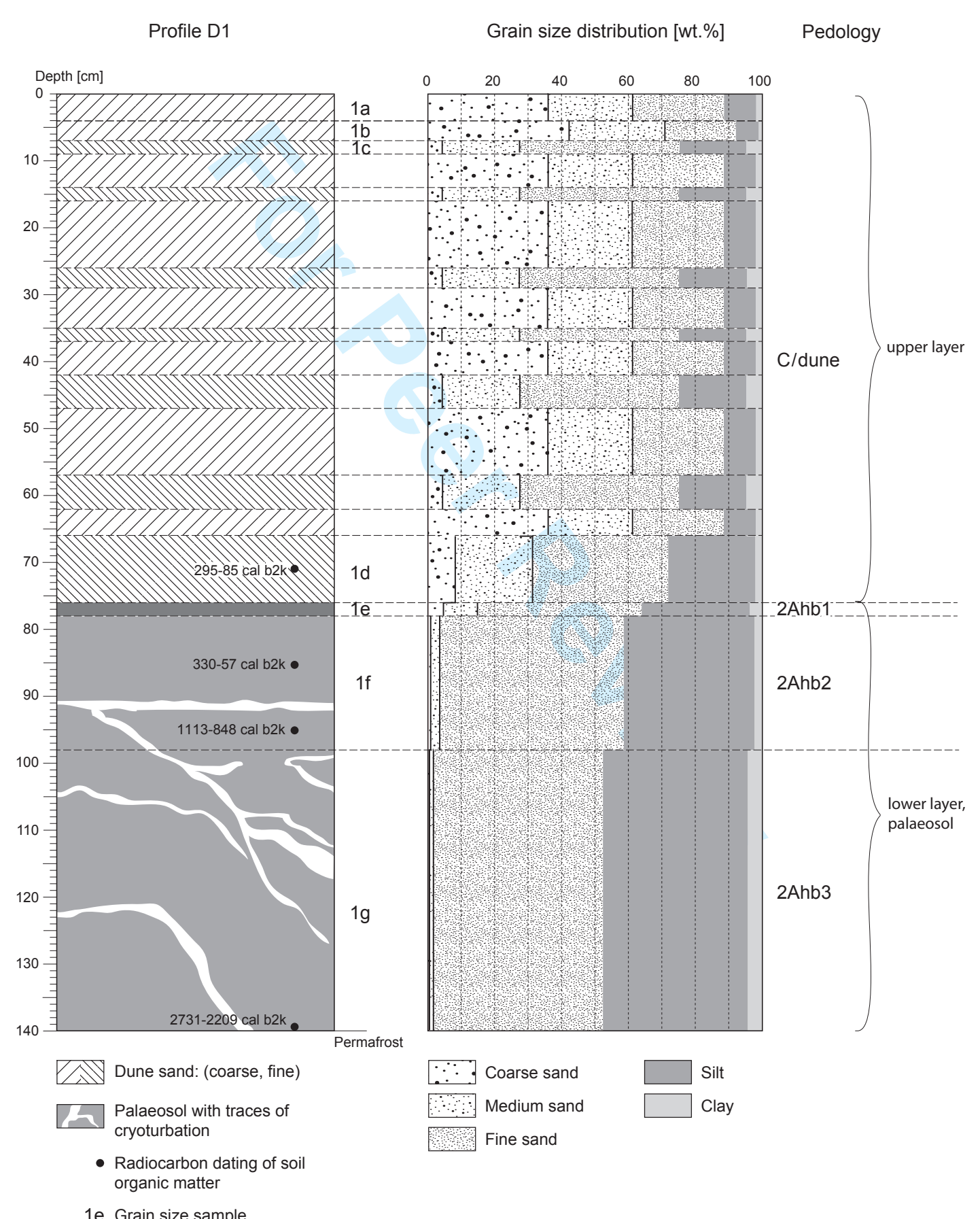




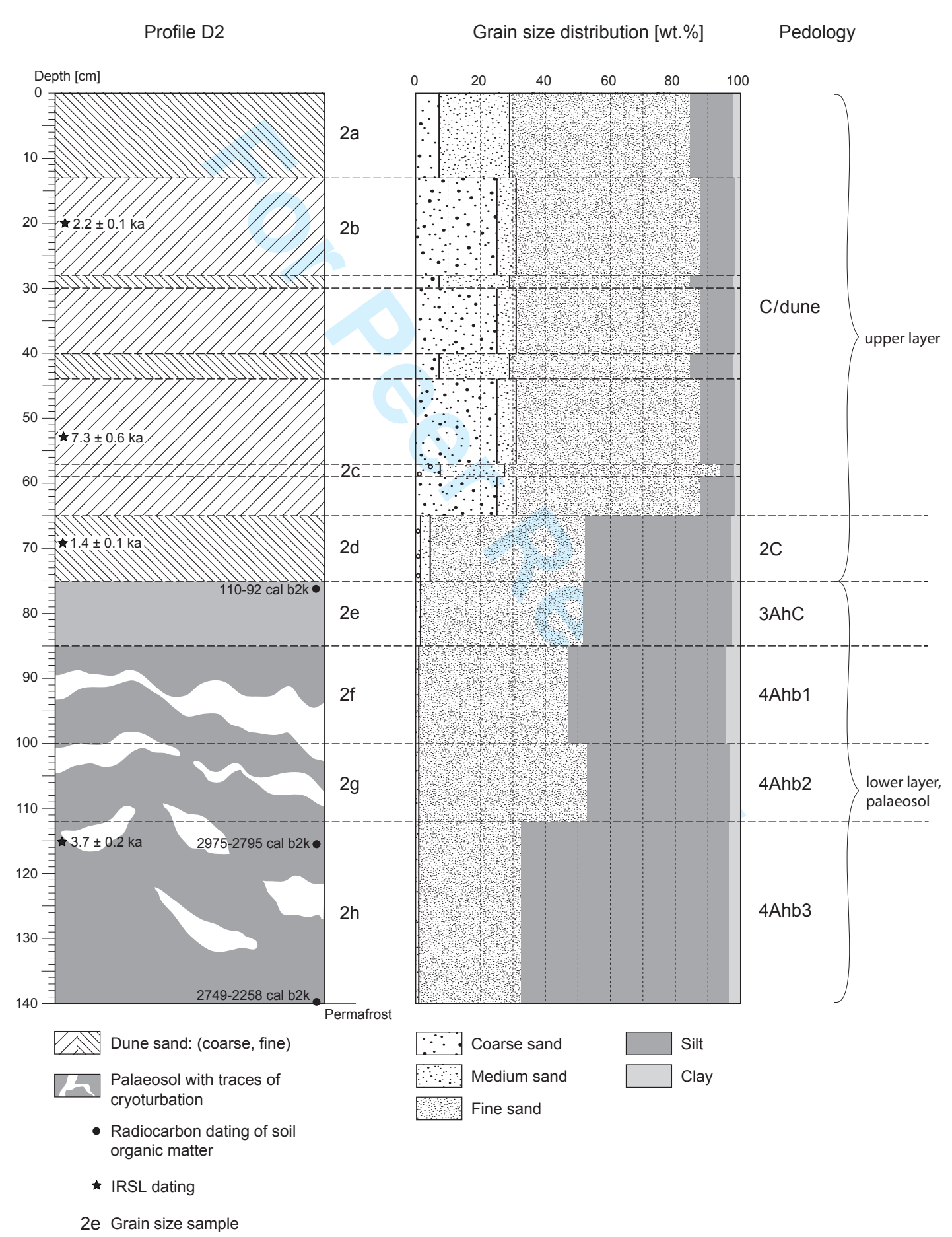




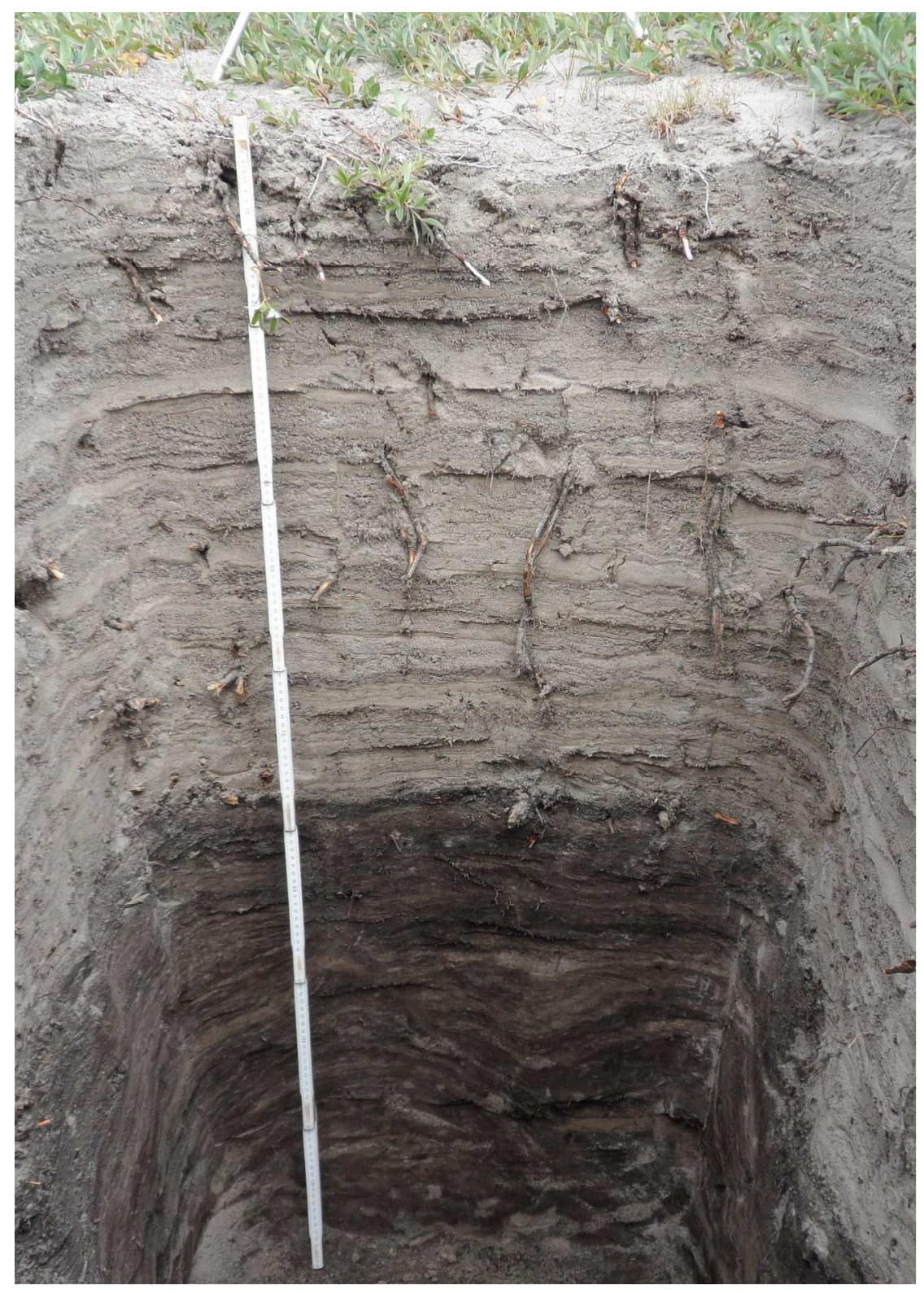

Figure 3. (c) Photo of profile D1 showing palaeosol (lower layer) and overlying dune sand (upper layer). Traces of cryoturbation are present in palaeosol. $647 \times 914 \mathrm{~mm}(96 \times 96 \mathrm{DPI})$ 


\section{Page 41 of 63}

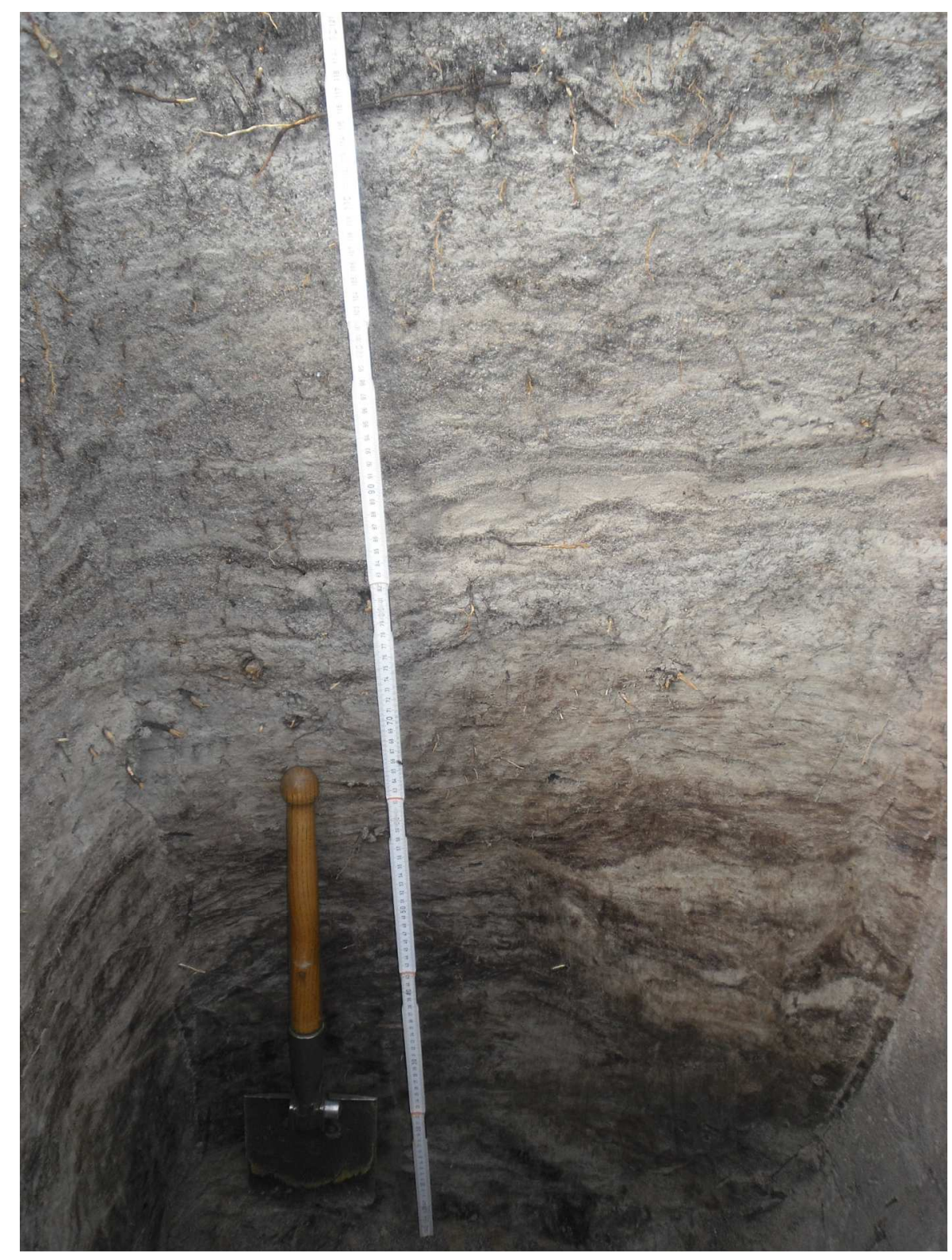

Figure 3. (d) Photo of profile D2 showing palaeosol (lower layer) and overlying dune sand (upper layer). Traces of cryoturbation are present in palaeosol. $609 \times 812 \mathrm{~mm}(72 \times 72$ DPI $)$ 


\section{HOLOCENE}

\begin{tabular}{lllll}
\hline Sedimentary unit & Location & Sand $( \pm$ SD) & Silt $( \pm$ SD $)$ & Clay $( \pm$ SD $)$ \\
\hline Upper + lower layer & Dunes & $63 \pm 20$ & $35 \pm 19$ & $2 \pm 1$ \\
& Cross-section 4 & $48 \pm 16$ & $49 \pm 15$ & $3 \pm 2$ \\
& Cross-section 3 & $49 \pm 17$ & $47 \pm 16$ & $4 \pm 3$ \\
& Cross-section 2 & $47 \pm 16$ & $50 \pm 16$ & $3 \pm 2$ \\
& Cross-section 1 & $46 \pm 14$ & $50 \pm 14$ & $4 \pm 2$ \\
Upper layer & & & & \\
& Dunes & $85 \pm 8$ & $13 \pm 7$ & $2 \pm 1$ \\
& Cross-section 4 & $47 \pm 12$ & $49 \pm 11$ & $4 \pm 2$ \\
& Cross-section 3 & $44 \pm 7$ & $51 \pm 7$ & $5 \pm 5$ \\
& Cross-section 2 & $40 \pm 7$ & $57 \pm 7$ & $3 \pm 2$ \\
Lower layer & Cross-section 1 & $42 \pm 6$ & $54 \pm 6$ & $4 \pm 2$ \\
& & & & \\
& Dunes & $48 \pm 9$ & $49 \pm 9$ & $3 \pm 1$ \\
& Cross-section 4 & $48 \pm 21$ & $50 \pm 21$ & $2 \pm 2$ \\
& Cross-section 3 & $55 \pm 23$ & $42 \pm 22$ & $3 \pm 2$ \\
& Cross-section 2 & $58 \pm 21$ & $39 \pm 19$ & $3 \pm 3$ \\
& Cross-section 1 & $50 \pm 20$ & $46 \pm 18$ & $4 \pm 2$ \\
\hline
\end{tabular}

1

2

3

4

5

6

10

11

12

13

14

15

16

17

18

19

20

21

22

23

24

25

26

27

28

29

30

31

32

33

34

35

36

37

38

39

40

41

42

43

44

45

46

47

48

49

50

51

52

53

54

55

56

57

58

59

60 
Figure 4. (a) Soil texture ternary diagrams (data shown in wt.\%). Lower layer of cross-sections 1 to 4 compared to lower layer of dunefields. Dune profiles show relatively fine, the sampling points from crosssection 1 to 4 partly coarse grain sizes. $296 \times 420 \mathrm{~mm}(300 \times 300$ DPI $)$ 
Figure 4. (b) Soil texture ternary diagrams (data shown in wt.\%). Upper layer of cross-sections 1 to 4 compared to the upper layer of dunefields. Highest sand contents, particularly in both coarse and medium sand range, were found in the dunefields. Cross-section 4 has higher contents of sandy loam compared to cross-sections 1 to 3 . $296 \times 420 \mathrm{~mm}(300 \times 300$ DPI) 
Figure 4. (c) Soil texture ternary diagrams (data shown in wt.\%). Lower layer of dunefields compared to the upper layer of cross-section 1 . Note that grain sizes from the lower layer of dune profiles are in the same range as from the upper layer of cross-section 1. $296 \times 420 \mathrm{~mm}(300 \times 300 \mathrm{DPI})$ 


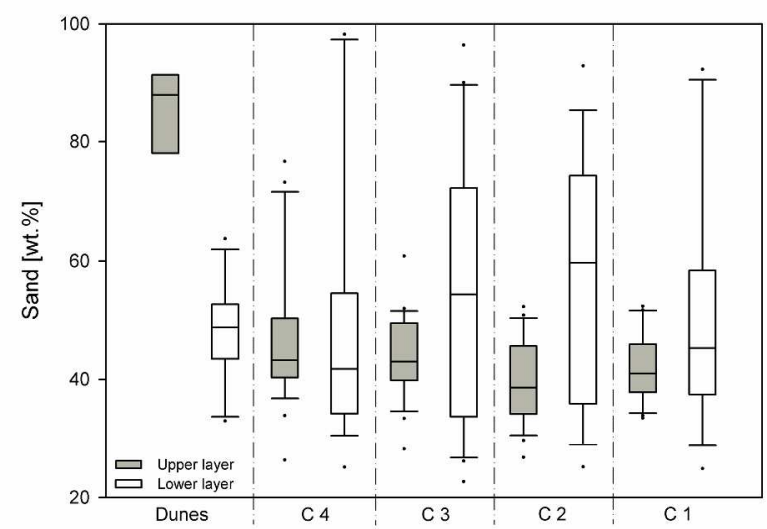

Figure 4. (d) Variability of sand content (wt.\%) in the upper layer and lower layer of dune sediments (Dunes) and cross-sections 1 to 4 (C1, C2, C3, C4). $296 \times 420 \mathrm{~mm}(300 \times 300 \mathrm{DPI})$ 
Figure 4. (e) Mean sand content (wt.\%) in the upper layer of dune sediments (filled dots) and cross-sections 1 to 4 (blank dots) with increasing distance $(\mathrm{m})$ from the ice margin.

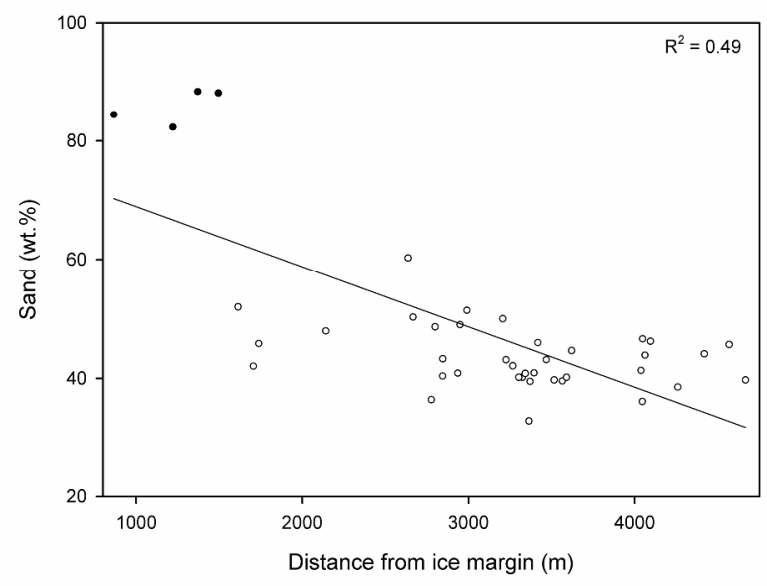




\begin{tabular}{|c|c|c|c|c|c|c|c|c|c|c|}
\hline $\begin{array}{l}\text { Chronological } \\
\text { process }\end{array}$ & Lab-No. & Sampling point/Location & $\begin{array}{l}\text { Calibrated } \\
\text { age [cal } \\
\text { b2k] }\end{array}$ & $\begin{array}{l}{ }^{14} \mathrm{C} \text { age } \\
{[\mathrm{BP}]}\end{array}$ & $\begin{array}{l}\text { Luminescence } \\
\text { age }[\mathrm{ka}]\end{array}$ & $\begin{array}{l}{ }^{10} \mathrm{Be} \text { age } \\
{[\mathrm{ka}]}\end{array}$ & Material & $\begin{array}{l}\text { Depth } \\
{[\mathrm{cm}]}\end{array}$ & Relevance [min./max. age] & Reference \\
\hline \multirow[t]{12}{*}{$\begin{array}{l}\text { Ørkendalen } \\
\text { moraine formation }\end{array}$} & UtC-1987 & $\begin{array}{l}\text { Sandflugtdalen } \\
\left(67.09^{\circ} \mathrm{N} / 50.29^{\circ} \mathrm{W}\right)\end{array}$ & $7533-7074$ & $6380 \pm 100$ & & & Gyttja (mud) & 200 & Max. Ørkendalen moraines & $\begin{array}{l}\text { Van Tatenhove et al. } \\
\text { (1996) }\end{array}$ \\
\hline & UtC-1990 & $\begin{array}{l}\text { Sandflugtdalen } \\
\left(67.09^{\circ} \mathrm{N} / 50.34^{\circ} \mathrm{W}\right)\end{array}$ & $7208-6850$ & $6090 \pm 50$ & & & Gyttja (mud) & No info & Max. Ørkendalen moraines & $\begin{array}{l}\text { Van Tatenhove et al. } \\
\text { (1996) }\end{array}$ \\
\hline & $\begin{array}{l}\text { LL0901- } \\
\text { LL0911 }\end{array}$ & $\begin{array}{l}\text { Sandflugtdalen } \\
\left(67.11^{\circ} \mathrm{N} / 50.29^{\circ} \mathrm{W} ;\right. \\
\left.67.16^{\circ} \mathrm{N} / 50.12^{\circ} \mathrm{W}\right)\end{array}$ & & & & $6.8 \pm 0.3$ & Boulders & No info & Max. Ørkendalen moraines & Levy et al. (2012) \\
\hline & UIC-1558 & Sandflugtdalen (no data) & & & $3.2-2.7$ & & Org. material & 35 & Min. Ørkendalen moraines & Forman et al. (2007) \\
\hline & UIC-1556 & Sandflugtdalen (no data) & & & $3.0-2.9$ & & Org. material & 28 & Min. Ørkendalen moraines & Forman et al. (2007) \\
\hline & Erl-16623 & $\begin{array}{l}\text { D2/Umimmalissuaq valley } \\
\left(66.56^{\circ} \mathrm{N} / 50.0^{\circ} \mathrm{W}\right)\end{array}$ & 2975-2795 & $2709 \pm 50$ & & & Org. material & $112-117$ & Min. Ørkendalen moraines & This study \\
\hline & Erl-19004 & $\begin{array}{l}\text { D2/Umimmalissuaq valley } \\
\left(66.56^{\circ} \mathrm{N} / 50.0^{\circ} \mathrm{W}\right)\end{array}$ & $2749-2258$ & $2361 \pm 50$ & & & Org. material & 140 & Min. Ørkendalen moraines & This study \\
\hline & Erl-19003 & $\begin{array}{l}\text { D1/Umimmalissuaq valley } \\
\left(66.56^{\circ} \mathrm{N} / 50.0^{\circ} \mathrm{W}\right)\end{array}$ & $2731-2209$ & $2333 \pm 51$ & & & Org. material & 140 & Min. Ørkendalen moraines & This study \\
\hline & No info & H1/Sandflugtdalen (no data) & $1941-1236$ & $1605 \pm 160$ & & & Org. material & $23-25$ & Min. Ørkendalen moraines & Ozols (2003) \\
\hline & No info & G1/Sandflugtdalen (no data) & $1866-1232$ & $1550 \pm 145$ & & & Org. material & $23-25$ & Min. Ørkendalen moraines & Ozols (2003) \\
\hline & No info & $\begin{array}{l}\text { Umimmalissuaq valley (no } \\
\text { data) }\end{array}$ & & & $1.4-1.0$ & & Peaty silt & 40 & Min. Ørkendalen moraines & $\begin{array}{l}\text { Scholz and } \\
\text { Grottenthaler (1988) }\end{array}$ \\
\hline & UW-180 & Lake Ørkendalen (no data) & $570-(-52)$ & $330 \pm 75$ & & & Plant residues & No info & Min. Ørkendalen moraines & Ten Brink (1975) \\
\hline $\begin{array}{l}\text { Retreat of ice } \\
\text { margin and start of } \\
\text { soil formation } \\
\text { (nalaeosols) }\end{array}$ & UtC-2034 & $\begin{array}{l}\text { Sandflugtdalen } \\
\left(67.10^{\circ} \mathrm{N} / 50.24^{\circ} \mathrm{W}\right)\end{array}$ & $4680-4490$ & $4060 \pm 60$ & & & Peat & No info & Start of soil formation & $\begin{array}{l}\text { Van Tatenhove et al. } \\
\text { (1996) }\end{array}$ \\
\hline
\end{tabular}




\begin{tabular}{|c|c|c|c|c|c|c|c|c|}
\hline & UtC-5624 & $\begin{array}{l}\text { PS4-Russell/P1 Base } \\
\text { Sandflugtdalen } \\
\left(67.05^{\circ} \mathrm{N} / 50.14^{\circ} \mathrm{W}\right)\end{array}$ & $3869-3123$ & $3200 \pm 130$ & Plant residues & No info & $\begin{array}{l}\text { Halt in aeolian sand } \\
\text { formation }\end{array}$ & Willemse et al. (2003) \\
\hline & GrN-14655 & $\begin{array}{l}\text { Sand sheet Sandflugtdalen } \\
\left(67.03^{\circ} \mathrm{N}, 50.24^{\circ} \mathrm{W}\right)\end{array}$ & $3442-3263$ & $3095 \pm 40$ & Sandy peat & No info & $\begin{array}{l}\text { Halt in aeolian sand } \\
\text { formation }\end{array}$ & $\begin{array}{l}\text { Dijkmans and Törnqvist } \\
\text { (1991) }\end{array}$ \\
\hline & Erl-16623 & $\begin{array}{l}\text { D2/Umimmalissuaq valley } \\
\left(66.56^{\circ} \mathrm{N} / 50.0^{\circ} \mathrm{W}\right)\end{array}$ & $2975-2795$ & $2709 \pm 50$ & Org. material & $112-117$ & $\begin{array}{l}\text { Min. Ørkendalen moraines, } \\
\text { start of soil formation }\end{array}$ & This study \\
\hline & Erl-19004 & $\begin{array}{l}\mathrm{D} 2 / \text { Umimmalissuaq valley } \\
\left(66.56^{\circ} \mathrm{N} / 50.0^{\circ} \mathrm{W}\right)\end{array}$ & $2749-2258$ & $2361 \pm 50$ & Org. material & 140 & Min. Ørkendalen moraines & This study \\
\hline & Erl-19003 & $\begin{array}{l}\text { D1/Umimmalissuaq valley } \\
\left(66.56^{\circ} \mathrm{N} / 50.0^{\circ} \mathrm{W}\right)\end{array}$ & 2731-2209 & $2333 \pm 51$ & Org. material & 140 & Min. Ørkendalen moraines & This study \\
\hline \multirow[t]{6}{*}{$\begin{array}{l}\text { Readvance of ice } \\
\text { margin and } \\
\text { (re)accumulation of } \\
\text { aeolian sand }\end{array}$} & Erl-16621 & $\begin{array}{l}\text { D1/Umimmalissuaq valley } \\
\left(66.56^{\circ} \mathrm{N} / 50.0^{\circ} \mathrm{W}\right)\end{array}$ & $1113-848$ & $1041 \pm 50$ & Org. material & 93-98 & $\begin{array}{l}\text { Halt in soil formation and } \\
\text { (re)accumulation of aeolian } \\
\text { sand }\end{array}$ & This study \\
\hline & Erl-19002 & $\begin{array}{l}\text { D1/Umimmalissuaq valley } \\
\left(66.56^{\circ} \mathrm{N} / 50.0^{\circ} \mathrm{W}\right)\end{array}$ & $330-57$ & $123 \pm 47$ & Org. material & 85 & $\begin{array}{l}\text { Halt in soil formation and } \\
\text { (re)accumulation of aeolian } \\
\text { sand }\end{array}$ & This study \\
\hline & Erl-16620 & $\begin{array}{l}\text { D1/Umimmalissuaq valley } \\
\left(66.56^{\circ} \mathrm{N} / 50.0^{\circ} \mathrm{W}\right)\end{array}$ & $295-85$ & $-204 \pm 45$ & Org. material & $66-76$ & $\begin{array}{l}\text { Halt in soil formation and } \\
\text { (re)accumulation of aeolian } \\
\text { sand }\end{array}$ & This study \\
\hline & Erl-16622 & $\begin{array}{l}\text { D2/Umimmalissuaq valley } \\
\left(66.56^{\circ} \mathrm{N} / 50.0^{\circ} \mathrm{W}\right)\end{array}$ & $110-92$ & $-349 \pm 44$ & Org. material & $71-76$ & $\begin{array}{l}\text { Halt in soil formation and } \\
\text { (re)accumulation of aeolian } \\
\text { sand }\end{array}$ & This study \\
\hline & GrN-14651 & $\begin{array}{l}\text { Sand sheet Ørkendalen } \\
\left(67.0^{\circ} \mathrm{N} / 50.28^{\circ} \mathrm{W}\right)\end{array}$ & $735-560$ & $610 \pm 80$ & Peaty silt & No info & $\begin{array}{l}\text { (Re)accumulation of } \\
\text { aeolian sand }\end{array}$ & $\begin{array}{l}\text { Dijkmans and Törnqvist } \\
\text { (1991) }\end{array}$ \\
\hline & UtC-5619 & $\begin{array}{l}\text { PS4-Russell/P1 Top } \\
\text { Sandlugtdalen } \\
\left(67.05^{\circ} \mathrm{N} / 50.14^{\circ} \mathrm{W}\right)\end{array}$ & $595-550$ & $487 \pm 30$ & Plant residues & No info & $\begin{array}{l}\text { (Re)accumulation of } \\
\text { aeolian sand }\end{array}$ & Willemse et al. (2003) \\
\hline
\end{tabular}




\begin{tabular}{|c|c|c|c|c|c|c|c|c|}
\hline \multirow[t]{4}{*}{ Additional data } & Erl-19000 & $\begin{array}{l}17 / \text { Umimmalissuaq valley } \\
\left(66.56^{\circ} \mathrm{N} / 50.47^{\circ} \mathrm{W}\right)\end{array}$ & $5335-4919$ & $4433 \pm 54$ & Org. material & 50 & $\begin{array}{l}\text { Min. Umîvît/Keglen, max. } \\
\text { Ørkendalen moraines }\end{array}$ & This study \\
\hline & Erl-16614 & $\begin{array}{l}\text { 33/Umimmalissuaq valley } \\
\left(66.56^{\circ} \mathrm{N} / 50.33^{\circ} \mathrm{W}\right)\end{array}$ & $4876-4499$ & $4114 \pm 53$ & Org. material & $60-62$ & $\begin{array}{l}\text { Min. Umîvît/Keglen, max. } \\
\text { Ørkendalen moraines }\end{array}$ & This study \\
\hline & Erl-19001 & $\begin{array}{l}\text { 24/ Umimmalissuaq valley } \\
\left(66.56^{\circ} \mathrm{N} / 50.37^{\circ} \mathrm{W}\right)\end{array}$ & $2975-2800$ & $2720 \pm 49$ & Org. material & 80 & $\begin{array}{l}\text { Min. Umîvît/Keglen, max. } \\
\text { Ørkendalen moraines }\end{array}$ & This study \\
\hline & Erl-16619 & $\begin{array}{l}\text { D0/Umimmalissuaq valley } \\
\left(66.56^{\circ} \mathrm{N} / 49.59^{\circ} \mathrm{W}\right)\end{array}$ & $310-76$ & $7 \pm 45$ & Org. material & $44-47$ & & This study \\
\hline
\end{tabular}

${ }^{\text {a }}$ Calibration was conducted using Oxcal version 4.2 (Bronk Ramsey, 2009) 


\section{Page 51 of 63}

HOLOCENE

\begin{tabular}{|c|c|c|c|c|c|c|c|c|c|c|c|c|}
\hline Field ID & Laboratory ID & $\begin{array}{l}\text { Sampling depth } \\
(\mathrm{cm})\end{array}$ & $\begin{array}{c}{ }^{226} \mathrm{Ra} \pm \text { s.e. } \\
(\mathrm{Bq} / \mathrm{kg})\end{array}$ & $\begin{array}{l}{ }^{232} \mathrm{Th} \pm \text { s.e. } \\
(\mathrm{Bq} / \mathrm{kg})\end{array}$ & $\begin{array}{l}{ }^{40} \mathrm{~K} \pm \text { s.e. } \\
(\mathrm{Bq} / \mathrm{kg})\end{array}$ & $\begin{array}{l}\text { Water content } \\
\text { (\%) }\end{array}$ & $\begin{array}{c}\text { Total dose rate } \pm \text { s.e. } \\
(\mathrm{Gy} / \mathrm{ka})\end{array}$ & $\mathrm{n}$ & $\begin{array}{c}\text { De } \pm \text { s.e. } \\
(\mathrm{Gy})\end{array}$ & $\begin{array}{c}g \text {-value } \\
(\% / \text { decade })\end{array}$ & $\begin{array}{l}\text { age } \pm \text { s.e. } \\
\quad(\mathrm{ka})\end{array}$ & $\begin{array}{l}\text { Fading corrected age } \pm \text { s.e. } \\
\qquad(\mathrm{ka})\end{array}$ \\
\hline D2 - 20 & 143078 & 20 & $2.83 \pm 0.27$ & $7.48 \pm 0.33$ & $486 \pm 10$ & 10.6 & $2.37 \pm 0.08$ & 12 & $3.2 \pm 0.2$ & $3.81 \pm 0.17$ & $1.6 \pm 0.1$ & $2.2 \pm 0.1$ \\
\hline $\mathrm{D} 2-53$ & 143079 & 53 & $3.49 \pm 0.25$ & $7.73 \pm 0.26$ & $453 \pm 8$ & 7.5 & $2.33 \pm 0.08$ & 12 & $12.8 \pm 0.8$ & $3.13 \pm 0.20$ & $5.5 \pm 0.4$ & $7.3 \pm 0.6$ \\
\hline D2 - 69 & 143080 & 69 & $6.62 \pm 0.31$ & $11.30 \pm 0.39$ & $453 \pm 9$ & 23.9 & $2.17 \pm 0.07$ & 12 & $2.4 \pm 0.1$ & $2.87 \pm 0.03$ & $1.1 \pm 0.1$ & $1.4 \pm 0.1$ \\
\hline D2 - 115 & 143081 & 115 & $7.62 \pm 0.47$ & $11.60 \pm 0.56$ & $404 \pm 11$ & 22.9 & $2.04 \pm 0.07$ & 12 & $5.7 \pm 0.1$ & $3.33 \pm 0.12$ & $2.8 \pm 0.1$ & $3.7 \pm 0.2$ \\
\hline
\end{tabular}

http://mc.manuscriptcentral.com/holocene 
Profile 17

Grain size distribution [wt.\%]

Pedology

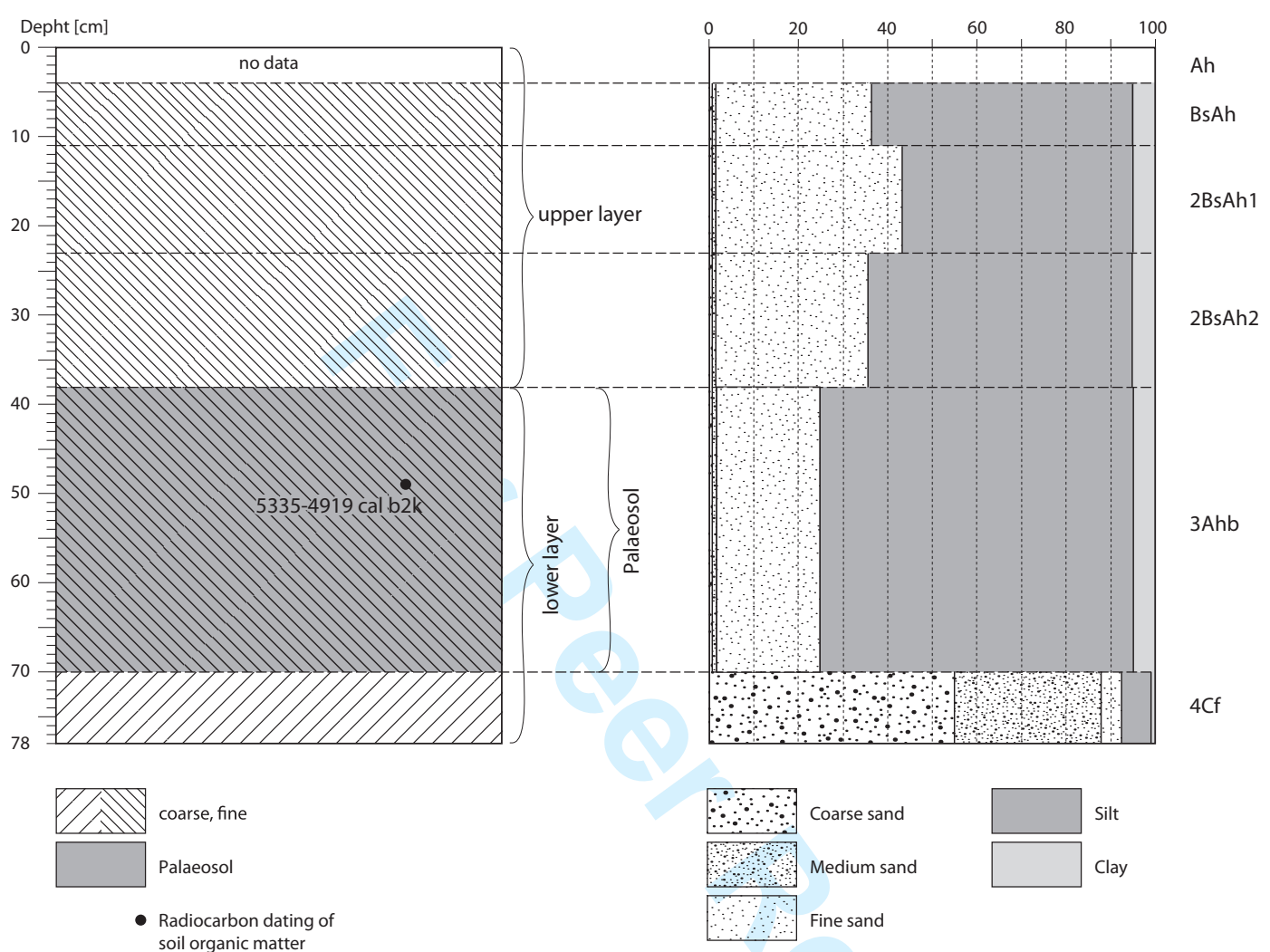




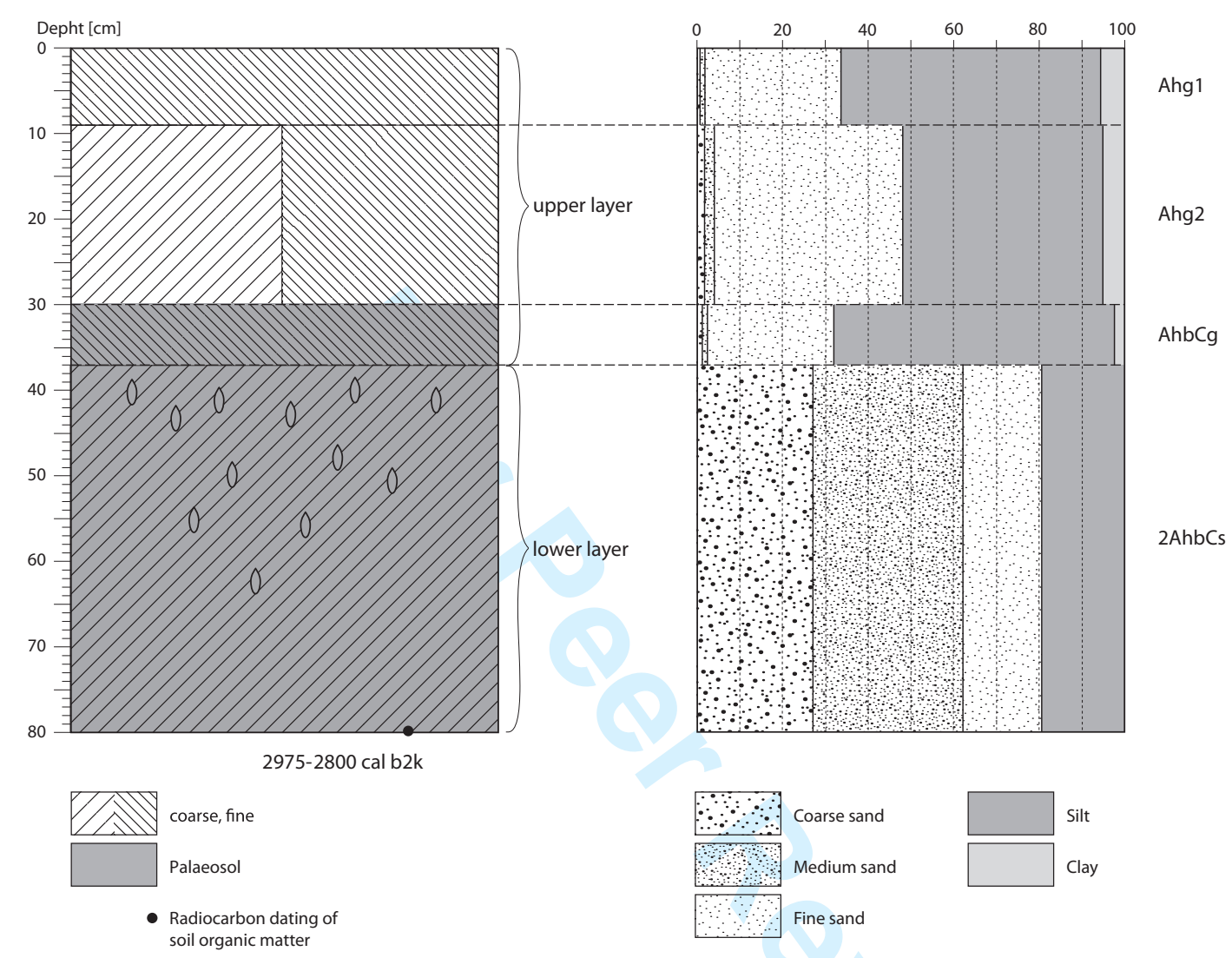




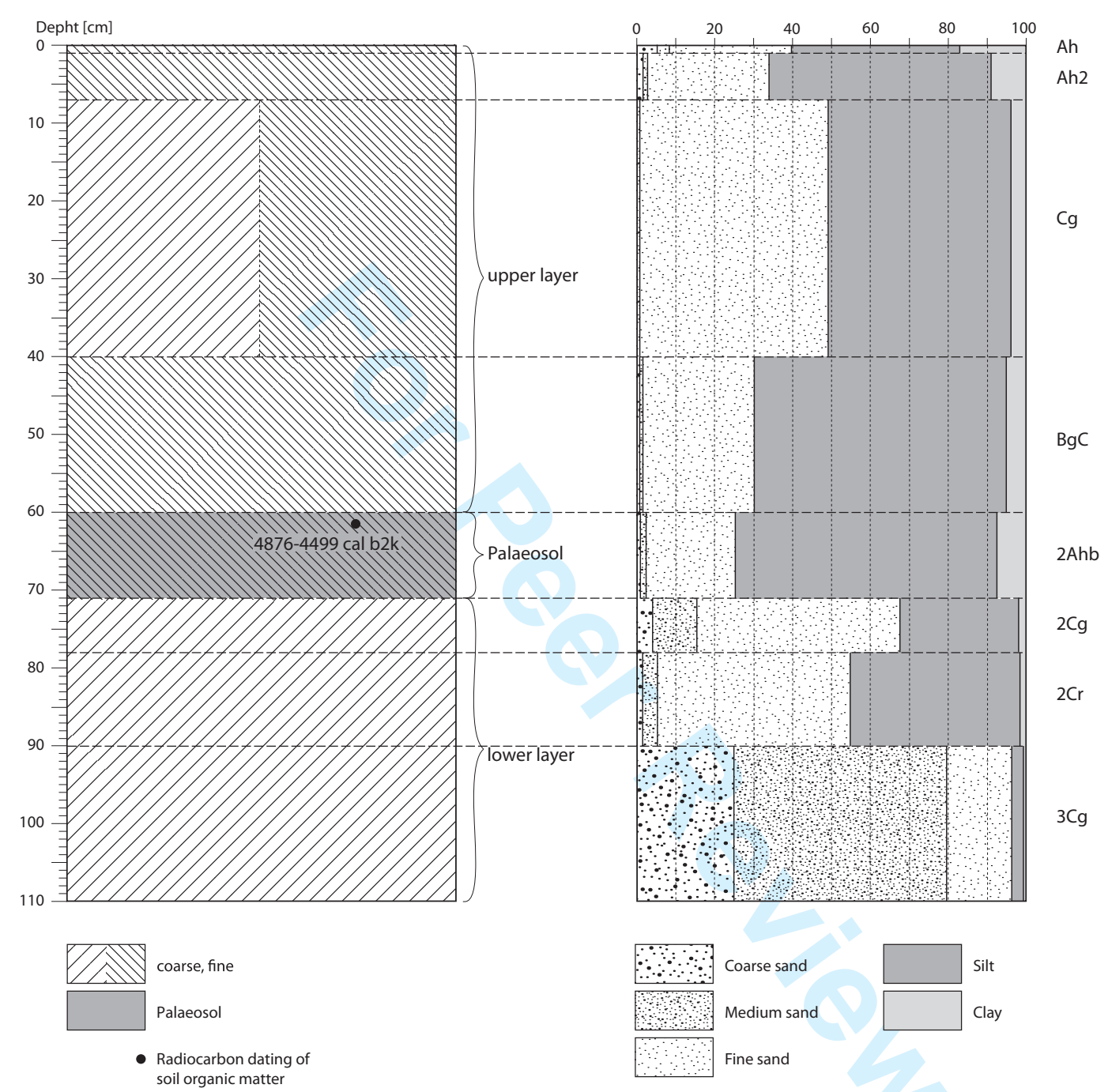




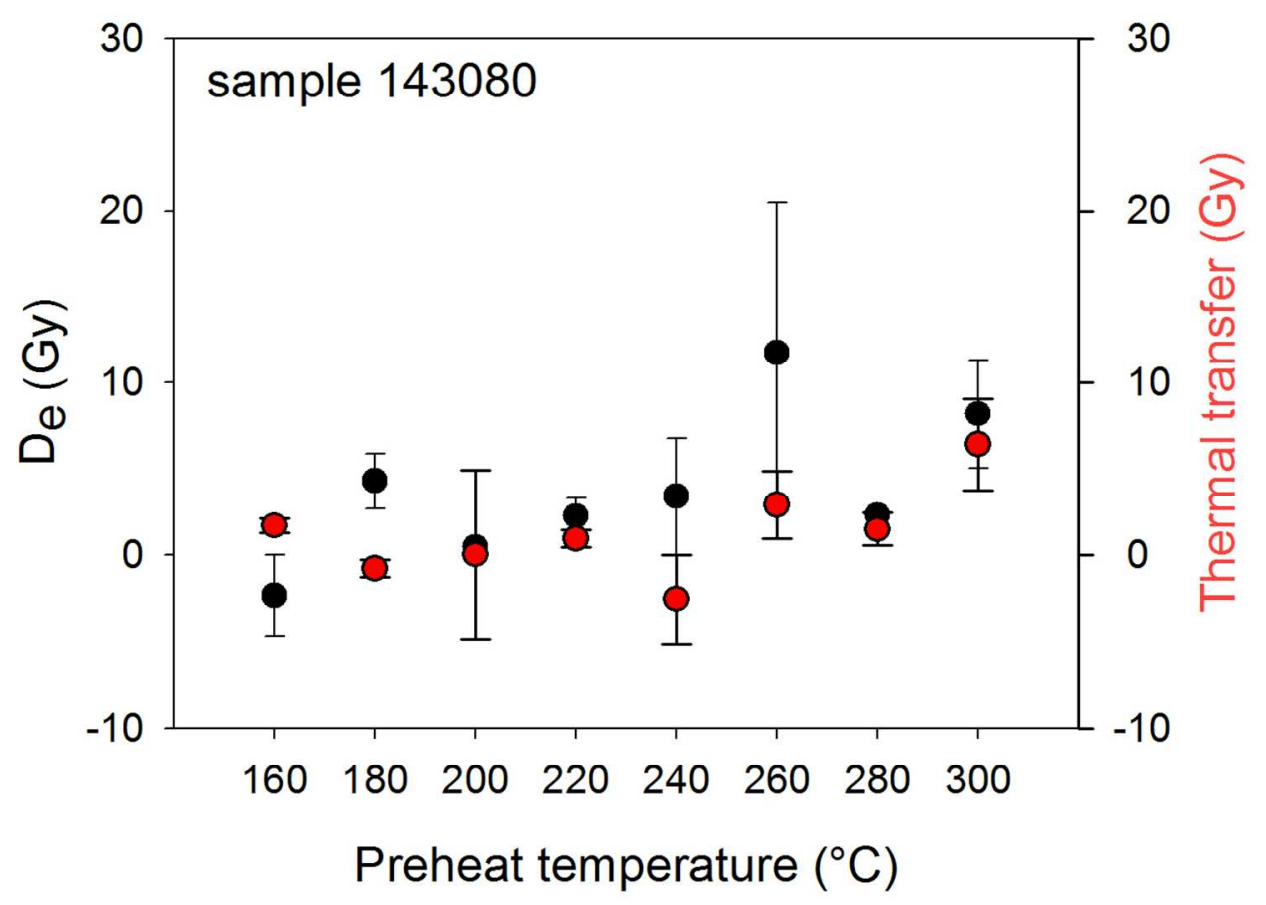

$114 \times 82 \mathrm{~mm}(300 \times 300$ DPI $)$ 

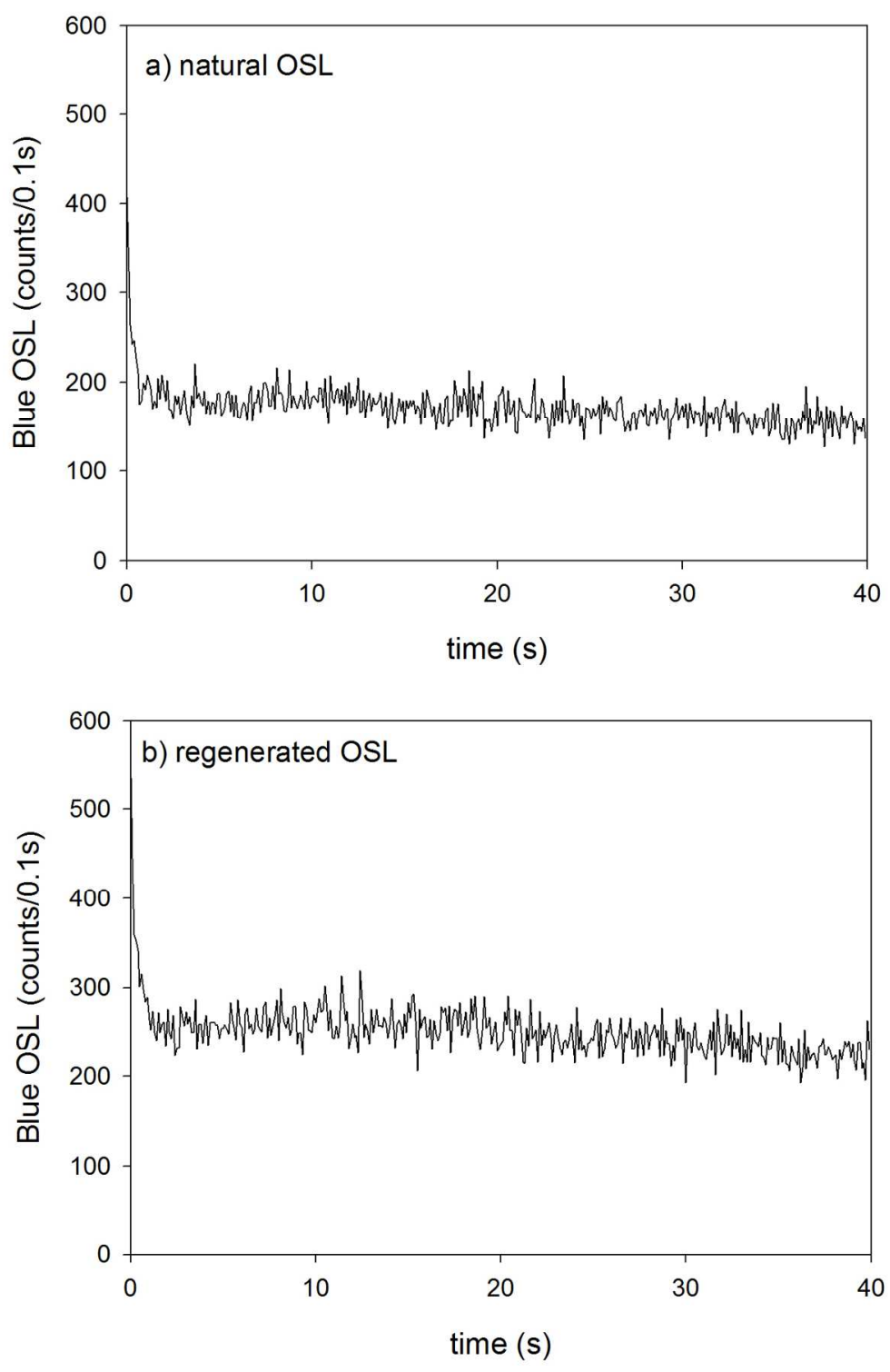

$121 \times 181 \mathrm{~mm}(300 \times 300$ DPI $)$ 


\begin{tabular}{|c|c|c|c|c|c|c|c|c|c|c|c|c|}
\hline & & & & & & & Sand & & & & Silt & Clay \\
\hline Profile & Horizon & Depth $[\mathrm{cm}]$ & $\mathrm{cS}$ & $\mathrm{mS}$ & fS & $\mathrm{ffS}$ & Sum & $\mathrm{cU}$ & $\mathrm{mU}$ & $\mathrm{fU}$ & Sum & Sum \\
\hline $10-1$ & OiOe & -3 & 1.3 & 1.3 & 2.2 & 29.1 & 34 & 55.8 & 6.5 & 0.9 & 63 & 2.8 \\
\hline $10-2$ & Ah & -9 & 0.3 & 1.0 & 2.0 & 30.3 & 34 & 54.6 & 8.0 & 1.4 & 64 & 2.5 \\
\hline $10-3$ & $2 \mathrm{Ah}$ & -12 & 0.5 & 1.1 & 2.2 & 32.4 & 36 & 52.7 & 6.3 & 1.2 & 60 & 3.6 \\
\hline $10-4$ & $2 \mathrm{C} / \mathrm{Ahb}$ & -38 & 0.4 & 0.9 & 2.9 & 36.5 & 41 & 47.4 & 8.6 & 1.1 & 57 & 2.2 \\
\hline $10-5$ & $2 \mathrm{Bhs}$ & $38-55+$ & 1.7 & 2.5 & 2.2 & 22.4 & 29 & 53.3 & 13.7 & 1.0 & 68 & 3.2 \\
\hline $11-1$ & CfAh1 & -50 & 0.2 & 1.2 & 6.1 & 50.1 & 58 & 34.6 & 2.7 & 0.6 & 38 & 4.5 \\
\hline $11-2$ & CfAh2 & -75 & & & & & No data & & & & & \\
\hline $11-3$ & CfAh3 & -100 & & & & & No data & & & & & \\
\hline $11-4$ & CfAh4 & -125 & & & & & No data & & & & & \\
\hline $12-1$ & $\mathrm{Ah}$ & -3 & 0.9 & 1.3 & 3.6 & 34.6 & 40 & 45.9 & 8.3 & 0.8 & 55 & 4.7 \\
\hline $12-2$ & CAh & -22 & 0.8 & 2.0 & 4.3 & 35.2 & 42 & 42.6 & 6.7 & 1.8 & 51 & 6.6 \\
\hline $12-3$ & $\mathrm{Cfh}$ & $22+$ & 0.6 & 1.4 & 6.2 & 44.3 & 53 & 38.0 & 4.4 & 0.5 & 43 & 4.5 \\
\hline $13-1$ & $\mathrm{Ah}$ & -6 & 1.3 & 2.1 & 3.4 & 34.2 & 41 & 43.2 & 8.0 & 1.4 & 53 & 6.4 \\
\hline $13-2$ & CAh1 & -27 & 0.2 & 0.6 & 5.0 & 46.5 & 52 & 38.2 & 5.0 & 0.3 & 43 & 4.3 \\
\hline $13-3$ & CAh2 & -49 & 0.7 & 1.1 & 3.1 & 36.7 & 42 & 44.8 & 7.0 & 0.0 & 52 & 6.5 \\
\hline $13-4$ & $\mathrm{C}$ & -60 & 2.7 & 4.4 & 3.4 & 27.0 & 37 & 46.9 & 10.7 & 0.3 & 58 & 4.6 \\
\hline $13-5$ & $\mathrm{Ah}$ & -80 & 1.4 & 2.8 & 2.9 & 24.4 & 32 & 45.7 & 12.4 & 2.5 & 61 & 7.8 \\
\hline $13-6$ & $\mathrm{C}$ & -90 & 12.3 & 13.1 & 5.2 & 17.4 & 48 & 36.2 & 10.6 & 0.7 & 48 & 4.4 \\
\hline $13-7$ & $\mathrm{Ah}$ & -95 & 6.8 & 9.6 & 4.5 & 16.6 & 38 & 40.8 & 13.7 & 2.7 & 57 & 5.2 \\
\hline $13-8$ & $\mathrm{C}$ & $95-117+$ & 10.1 & 16.6 & 6.9 & 16.4 & 50 & 33.7 & 10.8 & 1.5 & 46 & 4.0 \\
\hline $14-1$ & $\mathrm{Ah}$ & -2 & 0.4 & 0.8 & 2.5 & 35.6 & 39 & 49.5 & 6.1 & 1.3 & 57 & 3.7 \\
\hline $14-2$ & $\mathrm{AhC}$ & -27 & 0.0 & 1.1 & 4.7 & 42.4 & 48 & 41.9 & 6.3 & 0.5 & 49 & 2.8 \\
\hline $14-3$ & 2CAhb & -31 & 12.8 & 17.0 & 8.0 & 20.6 & 58 & 29.0 & 7.8 & 1.7 & 39 & 3.1 \\
\hline $14-4$ & $2 \mathrm{C}$ & $31-45+$ & 10.0 & 25.6 & 14.4 & 18.7 & 69 & 17.2 & 7.6 & 2.5 & 27 & 4.0 \\
\hline $15-1$ & CAh & -18 & 1.1 & 0.6 & 5.3 & 44.3 & 51 & 39.5 & 7.5 & 0.5 & 47 & 1.3 \\
\hline $15-2$ & $\mathrm{AhbC}$ & -40 & 0.1 & 0.3 & 3.5 & 37.3 & 41 & 45.2 & 4.3 & 1.3 & 51 & 7.9 \\
\hline $15-3$ & $2 \mathrm{Ahb}$ & -45 & 0.2 & 0.4 & 4.1 & 41.8 & 46 & 37.6 & 6.4 & 1.5 & 46 & 8.1 \\
\hline $15-4$ & $2 \mathrm{AhbC}$ & -65 & 0.0 & 0.4 & 2.3 & 35.1 & 38 & 49.7 & 3.5 & 0.7 & 54 & 8.3 \\
\hline $15-5$ & $3 \mathrm{Ahb}$ & -67 & & & & & No data & & & & & \\
\hline
\end{tabular}




\begin{tabular}{|c|c|c|c|c|c|c|c|c|c|c|c|c|}
\hline $15-6$ & $3 \mathrm{Bgb}$ & -74 & 1.2 & 2.7 & 2.5 & 23.0 & 29 & 50.0 & 14.9 & 1.6 & 67 & 4.1 \\
\hline $16-1$ & Ah & -12 & 0.3 & 1.1 & 2.8 & 35.2 & 39 & 48.0 & 7.2 & 1.3 & 57 & 4.0 \\
\hline $16-2$ & CAh & -22 & 0.1 & 0.7 & 3.0 & 37.4 & 41 & 46.3 & 7.7 & 1.0 & 55 & 3.7 \\
\hline $16-3$ & 2CAhb & -38 & 0.0 & 0.3 & 4.7 & 46.5 & 52 & 38.6 & 6.5 & 1.2 & 46 & 2.2 \\
\hline $16-4$ & $3 \mathrm{C}$ & $38+$ & 0.1 & 0.2 & 2.8 & 38.5 & 42 & 46.8 & 7.9 & 1.1 & 56 & 2.6 \\
\hline $17-1$ & Ah & -4 & & & & & No data & & & & & \\
\hline $17-2$ & BsAh & -11 & 0.2 & 0.3 & 2.7 & 33.1 & 36 & 49.4 & 7.8 & 1.0 & 58 & 5.5 \\
\hline $17-3$ & 2BsAh1 & -23 & 0.1 & 0.4 & 3.7 & 39.2 & 43 & 43.6 & 7.1 & 0.7 & 51 & 5.2 \\
\hline $17-4$ & 2BsAh2 & -38 & 0.2 & 0.2 & 2.0 & 33.4 & 36 & 48.4 & 8.7 & 1.2 & 58 & 5.9 \\
\hline $17-5$ & $3 \mathrm{Ahb}$ & -70 & 0.1 & 0.6 & 2.0 & 22.2 & 25 & 50.5 & 16.0 & 3.5 & 70 & 5.2 \\
\hline $17-6$ & $4 \mathrm{Cf}$ & $-78+\mathrm{PF}$ & 55.0 & 33.7 & 1.8 & 1.8 & 92 & 3.3 & 1.7 & 1.9 & 7 & 0.7 \\
\hline $18-1$ & CAh & -7 & & & & & No data & & & & & \\
\hline $18-2$ & Ahb & -22 & 0.1 & 0.5 & 3.6 & 37.4 & 42 & 45.1 & 7.7 & 2.0 & 55 & 3.6 \\
\hline $18-3$ & $2 \mathrm{CAhb}$ & -28 & 0.1 & 0.5 & 4.7 & 44.4 & 50 & 39.6 & 5.8 & 1.4 & 47 & 3.5 \\
\hline $18-4$ & $3 \mathrm{Ahb}$ & $28-40+$ & 0.2 & 0.4 & 4.2 & 40.4 & 45 & 42.7 & 6.8 & 1.0 & 51 & 4.2 \\
\hline $19-1$ & Ah & -2 & 7.4 & 10.0 & 4.8 & 17.5 & 40 & 42.0 & 14.9 & 2.6 & 59 & 0.8 \\
\hline $19-2$ & $\mathrm{AC}$ & -36 & 24.8 & 26.6 & 9.6 & 15.5 & 76 & 17.2 & 4.4 & 0.8 & 22 & 1.2 \\
\hline $19-3$ & $2 \mathrm{C}$ & $36-40+$ & 19.9 & 49.9 & 12.0 & 8.8 & 91 & 4.6 & 3.1 & 0.5 & 8 & 1.2 \\
\hline $20-1$ & $\mathrm{Ah}$ & -6 & 0.5 & 2.0 & 4.0 & 38.9 & 45 & 46.0 & 5.0 & 0.8 & 52 & 2.8 \\
\hline $20-2$ & $\mathrm{AhC}$ & -21 & 0.4 & 1.0 & 5.6 & 42.8 & 50 & 41.1 & 6.8 & 1.5 & 49 & 0.8 \\
\hline $20-3$ & CAh & -36 & 0.8 & 2.6 & 3.4 & 32.0 & 39 & 49.1 & 9.7 & 1.2 & 60 & 1.2 \\
\hline $20-4$ & $\mathrm{C}$ & -42 & 1.6 & 4.9 & 5.1 & 27.4 & 39 & 46.3 & 10.9 & 1.4 & 59 & 2.4 \\
\hline $21-1$ & Oi & -6 & & & & & No data & & 1 & & & \\
\hline $21-2$ & $\mathrm{AhC}$ & -32 & 0.2 & 0.9 & 3.9 & 34.7 & 40 & 44.2 & 8.9 & 2.5 & 56 & 4.8 \\
\hline $21-3$ & Ahb & -40 & 0.4 & 3.1 & 3.3 & 29.1 & 36 & 45.4 & 9.2 & 1.8 & 56 & 7.8 \\
\hline $22-1$ & $\mathrm{Ah}$ & -3 & 0.3 & 0.6 & 2.2 & 33.2 & 36 & 46.3 & 6.9 & 2.6 & 56 & 7.9 \\
\hline $22-2$ & CrAh & -22 & 1.0 & 1.2 & 6.7 & 43.4 & 52 & 35.5 & 5.1 & 1.5 & 42 & 5.8 \\
\hline $22-3$ & $\mathrm{AhCr}$ & -47 & 0.1 & 0.3 & 1.9 & 29.8 & 32 & 50.8 & 8.9 & 2.8 & 63 & 5.4 \\
\hline $22-4$ & $2 \mathrm{Oe}$ & -61 & 0.3 & 1.0 & 1.9 & 22.0 & 25 & 47.7 & 10.7 & 4.3 & 63 & 12.2 \\
\hline $22-5$ & $2 \mathrm{Oi}$ & -70 & & & & & No data & & & & & \\
\hline $22-6$ & $3 \mathrm{C}$ & $-82+$ & 5.9 & 28.6 & 21.3 & 24.2 & 80 & 14.7 & 2.7 & 1.1 & 18 & 1.6 \\
\hline
\end{tabular}




\begin{tabular}{|c|c|c|c|c|c|c|c|c|c|c|c|c|}
\hline $23-1$ & Ah & -2 & 0.3 & 2.5 & 3.1 & 30.8 & 37 & 47.3 & 7.4 & 1.8 & 56 & 6.9 \\
\hline $23-2$ & AhgC & -28 & 0.1 & 0.5 & 3.5 & 38.7 & 43 & 45.0 & 7.2 & 0.8 & 53 & 4.2 \\
\hline $23-3$ & Bs & -33 & 9.9 & 21.5 & 11.0 & 17.4 & 60 & 24.2 & 10.3 & 2.3 & 37 & 3.5 \\
\hline $23-4$ & $2 \mathrm{Cg}$ & -41 & 13.7 & 25.2 & 11.9 & 15.1 & 66 & 18.6 & 9.9 & 1.9 & 30 & 3.6 \\
\hline $23-5$ & $3 \mathrm{C}$ & -44 & 12.0 & 16.1 & 11.8 & 20.0 & 60 & 24.8 & 10.6 & 2.0 & 37 & 2.7 \\
\hline $23-6$ & $4 C$ & -59 & 1.4 & 10.7 & 14.5 & 31.7 & 58 & 30.6 & 6.8 & 0.4 & 38 & 3.9 \\
\hline $23-7$ & $5 \mathrm{Cd}$ & $-78+$ & 22.4 & 48.9 & 13.0 & 8.7 & 93 & 3.8 & 1.0 & 0.1 & 5 & 2.1 \\
\hline $24-1$ & Ahg1 & -9 & 0.3 & 0.7 & 2.7 & 30.1 & 34 & 50.8 & 7.6 & 1.7 & 60 & 6.2 \\
\hline $24-2$ & Ahg2 & -30 & 1.5 & 2.3 & 4.4 & 39.8 & 48 & 38.3 & 5.5 & 2.8 & 47 & 5.4 \\
\hline $24-3$ & $\mathrm{AhbCg}$ & -37 & 1.1 & 1.2 & 1.8 & 27.4 & 31 & 53.5 & 11.3 & 1.3 & 66 & 2.5 \\
\hline $24-4$ & 2AhbCs & $-70+$ & 26.8 & 35.5 & 8.4 & 9.7 & 80 & 12.9 & 5.2 & 1.5 & 20 & 0.0 \\
\hline $25-1$ & $\mathrm{Ah}$ & -4 & 0.2 & 0.3 & 1.8 & 31.6 & 34 & 55.0 & 6.5 & 1.3 & 63 & 3.4 \\
\hline $25-2$ & CAh & -10 & 0.0 & 0.3 & 3.3 & 37.3 & 41 & 46.3 & 9.2 & 1.7 & 57 & 2.0 \\
\hline $25-3$ & $2 \mathrm{C} 1$ & -21 & 0.6 & 0.6 & 1.7 & 26.8 & 30 & 57.3 & 10.1 & 1.9 & 69 & 0.9 \\
\hline $25-4$ & $2 \mathrm{C} 2$ & -34 & 3.3 & 3.7 & 2.2 & 17.6 & 27 & 54.3 & 15.9 & 1.7 & 72 & 1.2 \\
\hline $25-5$ & $3 \mathrm{C}$ & $-49+$ & 24.9 & 28.0 & 10.5 & 10.9 & 74 & 16.4 & 6.9 & 1.3 & 25 & 1.1 \\
\hline $26-1$ & $\mathrm{Ah}$ & -23 & 0.0 & 0.4 & 3.6 & 37.9 & 42 & 43.7 & 7.1 & 2.6 & 53 & 4.6 \\
\hline $26-2$ & $\mathrm{AhC}$ & -40 & 0.0 & 0.2 & 2.2 & 35.9 & 38 & 49.7 & 6.7 & 1.2 & 58 & 4.1 \\
\hline $26-3$ & $\mathrm{C}$ & -50 & 0.1 & 0.4 & 2.0 & 29.0 & 32 & 53.3 & 12.2 & 1.5 & 67 & 1.5 \\
\hline $26-4$ & $2 \mathrm{C}$ & $-100+$ & 17.5 & 21.9 & 5.5 & 11.2 & 56 & 30.5 & 11.2 & 1.0 & 43 & 1.3 \\
\hline $27-1$ & $\mathrm{AhC1}$ & -3 & 1.6 & 3.1 & 5.2 & 36.6 & 47 & 41.9 & 7.3 & 1.1 & 50 & 3.2 \\
\hline $27-2$ & $\mathrm{AhC} 2$ & -8 & 0.1 & 1.0 & 4.0 & 32.1 & 37 & 46.5 & 10.2 & 1.1 & 58 & 4.9 \\
\hline $27-3$ & $2 \mathrm{Ahb}$ & -12 & 0.1 & 0.6 & 4.5 & 45.5 & 51 & 39.3 & 6.3 & 0.4 & 46 & 3.2 \\
\hline $27-4$ & $3 \mathrm{AhC1}$ & -27 & 0.0 & 0.3 & 2.4 & 32.2 & 35 & 52.6 & 8.8 & 0.9 & 62 & 2.8 \\
\hline $27-5$ & $3 \mathrm{AhC} 2$ & -40 & 0.9 & 3.6 & 3.3 & 23.6 & 31 & 50.4 & 13.8 & 1.3 & 65 & 3.0 \\
\hline $28-1$ & Ah & -1 & 12.6 & 5.9 & 3.3 & 23.9 & 46 & 39.5 & 11.8 & 1.2 & 52 & 1.9 \\
\hline $28-2$ & $\mathrm{C}$ & -18 & 9.4 & 9.1 & 3.9 & 16.0 & 39 & 42.6 & 15.5 & 1.9 & 60 & 1.5 \\
\hline $28-3$ & $2 \mathrm{C}$ & $-78+$ & 13.4 & 27.5 & 13.9 & 17.3 & 72 & 14.7 & 8.0 & 3.0 & 26 & 2.1 \\
\hline $30-1$ & $\mathrm{Ah}$ & -7 & 0.7 & 1.7 & 4.2 & 39.7 & 46 & 42.3 & 6.1 & 1.0 & 49 & 4.3 \\
\hline $30-2$ & CAh1 & -15 & 0.0 & 0.4 & 3.7 & 36.6 & 41 & 46.5 & 9.0 & 1.7 & 57 & 2.0 \\
\hline $30-3$ & CAh2 & -41 & 0.1 & 0.4 & 3.0 & 38.7 & 42 & 46.7 & 8.3 & 0.8 & 56 & 1.9 \\
\hline
\end{tabular}




\begin{tabular}{|c|c|c|c|c|c|c|c|c|c|c|c|c|}
\hline $30-4$ & $2 \mathrm{C}$ & -63 & 30.3 & 33.5 & 12.8 & 11.6 & 88 & 6.6 & 3.3 & 0.6 & 11 & 1.3 \\
\hline $30-5$ & $3 \mathrm{C}$ & -83 & 15.2 & 30.1 & 13.0 & 16.0 & 74 & 15.0 & 7.4 & 1.9 & 24 & 1.4 \\
\hline $31-1$ & $\mathrm{Ah}$ & -4 & 1.4 & 2.3 & 3.4 & 34.5 & 42 & 44.6 & 6.7 & 1.4 & 53 & 5.6 \\
\hline $31-2$ & CAh & -13 & 0.5 & 2.0 & 5.5 & 37.9 & 46 & 41.5 & 10.0 & 1.3 & 53 & 1.3 \\
\hline $31-3$ & 2CAh1 & -40 & 0.3 & 0.5 & 5.7 & 43.9 & 50 & 37.2 & 5.9 & 0.3 & 44 & 6.1 \\
\hline $31-4$ & 2CAh2 & -75 & 0.9 & 1.0 & 2.0 & 31.1 & 35 & 48.9 & 8.0 & 0.5 & 57 & 7.6 \\
\hline $32-1$ & $\mathrm{Ah}$ & -4 & & & & & No data & & & & & \\
\hline $32-2$ & $\mathrm{C} 1$ & -12 & 0.0 & 0.3 & 4.5 & 38.3 & 43 & 47.8 & 5.7 & 0.7 & 54 & 2.7 \\
\hline $32-3$ & $\mathrm{C} 2$ & -39 & 0.9 & 1.3 & 2.3 & 31.3 & 36 & 50.3 & 10.2 & 1.1 & 62 & 2.5 \\
\hline $32-4$ & $2 \mathrm{C}$ & -115 & 9.0 & 27.0 & 15.5 & 20.1 & 72 & 16.5 & 5.9 & 2.4 & 25 & 3.7 \\
\hline $33-1$ & $\mathrm{Ah}$ & -1 & 5.9 & 2.1 & 2.8 & 28.8 & 40 & 30.7 & 9.6 & 3.0 & 43 & 17.0 \\
\hline $33-2$ & Ah2 & -7 & 1.7 & 1.3 & 2.1 & 28.4 & 33 & 49.3 & 6.5 & 1.8 & 58 & 8.9 \\
\hline $33-3$ & $\mathrm{Cg}$ & -40 & 0.0 & 0.3 & 4.4 & 44.5 & 49 & 40.3 & 5.4 & 1.3 & 47 & 3.6 \\
\hline $33-4$ & $\mathrm{BgC}$ & -60 & 0.3 & 0.7 & 2.4 & 26.8 & 30 & 51.6 & 10.5 & 2.4 & 65 & 5.2 \\
\hline $33-5$ & $2 \mathrm{Ahb}$ & -71 & 0.5 & 1.3 & 2.3 & 22.0 & 26 & 47.8 & 14.3 & 4.2 & 66 & 7.6 \\
\hline $33-6$ & $2 \mathrm{Cg}$ & -78 & 3.9 & 11.9 & 16.8 & 34.4 & 67 & 24.0 & 5.4 & 1.8 & 31 & 1.8 \\
\hline $33-7$ & $2 \mathrm{Cr}$ & -90 & 1.2 & 4.1 & 9.3 & 39.6 & 54 & 34.4 & 8.2 & 1.8 & 44 & 1.4 \\
\hline $33-8$ & $3 \mathrm{Cg}$ & -110 & 24.2 & 54.9 & 11.3 & 6.1 & 96 & 2.4 & 0.4 & 0.1 & 3 & 0.7 \\
\hline $34-1$ & $\mathrm{Ah}$ & -4 & 0.2 & 0.9 & 2.2 & 36.5 & 40 & 47.5 & 6.8 & 1.7 & 56 & 4.2 \\
\hline $34-2$ & CAh & -26 & 0.2 & 1.2 & 4.2 & 40.8 & 46 & 43.6 & 6.2 & 0.7 & 51 & 3.0 \\
\hline $34-3$ & $\mathrm{C}$ & $-45+$ & 1.3 & 1.8 & 2.2 & 23.7 & 29 & 53.5 & 13.8 & 1.9 & 69 & 1.8 \\
\hline $35-1$ & $\mathrm{Ah}$ & -5 & 0.6 & 2.0 & 4.1 & 32.4 & 39 & 42.0 & 9.3 & 3.0 & 54 & 6.5 \\
\hline $35-2$ & $\mathrm{Bg}$ & -43 & 0.7 & 4.2 & 10.4 & 45.6 & 61 & 33.5 & 3.8 & 0.6 & 38 & 1.3 \\
\hline $35-3$ & Wrl1 & -52 & 0.7 & 4.1 & 12.2 & 34.8 & 52 & 38.4 & 6.9 & 1.3 & 47 & 1.6 \\
\hline $35-4$ & $\mathrm{Wr} 2$ & $-52+$ & 0.1 & 12.5 & 39.6 & 37.8 & 90 & 8.4 & 0.4 & 0.3 & 9 & 0.7 \\
\hline $36-1$ & $\mathrm{Ah}$ & -9 & 2.7 & 11.2 & 7.7 & 29.3 & 51 & 35.3 & 5.4 & 1.8 & 42 & 6.6 \\
\hline $36-2$ & CAh & -48 & 2.0 & 4.0 & 8.1 & 37.7 & 52 & 38.1 & 3.6 & 1.1 & 43 & 5.3 \\
\hline $36-3$ & $2 \mathrm{CAh}$ & -94 & 0.3 & 1.3 & 4.1 & 42.4 & 48 & 42.1 & 5.7 & 0.0 & 48 & 4.1 \\
\hline $37-1$ & $\mathrm{Ah}$ & -8 & 0.3 & 1.5 & 3.9 & 37.2 & 43 & 40.1 & 7.8 & 1.7 & 50 & 7.6 \\
\hline $37-2$ & CAh1 & -47 & 0.1 & 0.5 & 3.5 & 39.6 & 44 & 41.6 & 6.5 & 1.5 & 50 & 6.7 \\
\hline $37-3$ & $\mathrm{CAh} 2$ & -61 & 0.0 & 0.3 & 2.1 & 32.5 & 35 & 50.3 & 5.4 & 3.5 & 59 & 5.9 \\
\hline
\end{tabular}




\begin{tabular}{|c|c|c|c|c|c|c|c|c|c|c|c|c|}
\hline $37-4$ & 2CAhb & & 0.0 & 0.2 & 1.5 & 31.1 & 33 & 52.2 & 7.9 & 2.2 & 62 & 5.0 \\
\hline $38-1$ & $\mathrm{Ah}$ & -5 & 0.0 & 0.2 & 1.2 & 26.8 & 28 & 56.9 & 8.4 & 1.5 & 67 & 5.0 \\
\hline $38-2$ & CAh1 & -16 & 0.1 & 0.2 & 3.5 & 37.2 & 41 & 46.6 & 9.0 & 1.4 & 57 & 2.0 \\
\hline $38-3$ & CAh2 & -30 & 0.0 & 0.1 & 2.3 & 37.5 & 40 & 48.4 & 9.1 & 0.8 & 58 & 1.7 \\
\hline $38-4$ & $2 \mathrm{C}$ & -46 & 0.2 & 0.6 & 1.6 & 20.2 & 23 & 58.7 & 15.4 & 2.0 & 76 & 1.3 \\
\hline $38-5$ & $3 \mathrm{C} 1$ & -71 & 9.1 & 25.3 & 12.8 & 17.1 & 64 & 19.7 & 11.5 & 3.9 & 35 & 0.6 \\
\hline $38-6$ & $3 \mathrm{C} 2$ & $-71+$ & 15.3 & 26.5 & 14.0 & 17.1 & 73 & 15.5 & 7.8 & 3.1 & 26 & 0.6 \\
\hline $39-1$ & $\mathrm{Ah}$ & -6 & 3.7 & 4.8 & 4.5 & 36.5 & 49 & 39.7 & 6.1 & 1.3 & 47 & 3.5 \\
\hline $39-2$ & CAh & -35 & 0.9 & 1.6 & 4.6 & 44.0 & 51 & 39.9 & 6.1 & 0.5 & 46 & 2.4 \\
\hline $39-3$ & $2 \mathrm{Ahb}$ & -58 & 0.9 & 1.3 & 2.1 & 30.4 & 35 & 52.5 & 9.1 & 2.0 & 64 & 1.8 \\
\hline $39-4$ & $3 \mathrm{C}$ & -79 & 14.8 & 25.7 & 12.5 & 15.7 & 69 & 18.8 & 7.6 & 2.8 & 29 & 2.2 \\
\hline $39-5$ & $4 \mathrm{C}$ & $-79+$ & 15.3 & 26.7 & 12.6 & 16.0 & 71 & 15.0 & 8.7 & 3.5 & 27 & 2.2 \\
\hline $40-1$ & $\mathrm{AhC}$ & -10 & 1.0 & 1.5 & 3.2 & 35.3 & 41 & 45.4 & 8.6 & 1.0 & 55 & 4.0 \\
\hline $40-2$ & CAhg & -20 & 0.9 & 1.4 & 5.0 & 43.2 & 51 & 39.6 & 5.2 & 0.6 & 45 & 4.1 \\
\hline $40-3$ & CAhgb & -37 & 0.7 & 1.2 & 5.2 & 48.3 & 55 & 32.4 & 4.7 & 2.5 & 40 & 5.0 \\
\hline $40-4$ & Oeg & -43 & 0.5 & 1.1 & 5.6 & 48.1 & 55 & 31.7 & 3.3 & 2.0 & 37 & 7.6 \\
\hline $40-5$ & Arhf & -50 & 0.5 & 1.8 & 5.2 & 47.2 & 55 & 36.2 & 3.6 & 0.9 & 41 & 4.5 \\
\hline $41-1$ & $\mathrm{OaAh}$ & -14 & 2.9 & 2.5 & 3.4 & 30.9 & 40 & 49.4 & 4.0 & 0.5 & 54 & 6.5 \\
\hline $41-2$ & $\mathrm{Ah}$ & -20 & 0.4 & 1.0 & 3.8 & 34.9 & 40 & 45.3 & 8.3 & 2.0 & 56 & 4.4 \\
\hline $41-3$ & Oef & $-20+$ & 0.2 & 1.1 & 4.3 & 37.2 & 43 & 42.5 & 6.3 & 1.9 & 51 & 6.6 \\
\hline $42-1$ & $\mathrm{Ah}$ & -4 & 0.4 & 1.5 & 3.1 & 34.7 & 40 & 43.0 & 7.9 & 2.2 & 53 & 7.2 \\
\hline $42-2$ & $\mathrm{AhC}$ & -23 & 0.1 & 0.4 & 3.4 & 37.7 & 42 & 46.4 & 7.1 & 1.8 & 55 & 3.2 \\
\hline $42-3$ & $2 \mathrm{Ch}$ & -39 & 4.9 & 8.2 & 4.2 & 22.5 & 40 & 42.2 & 12.9 & 2.6 & 58 & 2.4 \\
\hline $42-4$ & 3CAhb & -50 & 1.5 & 2.3 & 2.6 & 31.8 & 38 & 46.1 & 10.4 & 1.7 & 58 & 3.6 \\
\hline $42-5$ & $4 \mathrm{C}$ & -52 & 5.3 & 7.2 & 4.3 & 23.2 & 40 & 42.5 & 12.7 & 2.1 & 57 & 2.7 \\
\hline $42-6$ & $5 \mathrm{C}$ & -54 & 8.0 & 11.7 & 5.4 & 19.9 & 45 & 39.4 & 11.2 & 2.7 & 53 & 1.7 \\
\hline $43-1$ & $\mathrm{Ah}$ & -10 & 2.1 & 3.0 & 6.8 & 34.4 & 46 & 41.4 & 7.0 & 1.3 & 50 & 3.9 \\
\hline $43-2$ & $2 \mathrm{Cg}$ & -13 & 4.1 & 23.2 & 16.4 & 29.4 & 73 & 22.2 & 3.3 & 1.2 & 27 & 0.1 \\
\hline $43-3$ & $2 \mathrm{AhgC}$ & $18-27$ & 0.0 & 0.4 & 3.2 & 22.7 & 26 & 37.1 & 21.1 & 8.8 & 67 & 6.7 \\
\hline $43-4$ & 3Ahgb & $54-77$ & 1.7 & 5.1 & 4.9 & 21.2 & 33 & 48.1 & 13.2 & 2.6 & 64 & 3.3 \\
\hline $44-1$ & CAh & -26 & 3.4 & 7.8 & 8.5 & 57.0 & 77 & 20.5 & 1.2 & 0.8 & 23 & 0.8 \\
\hline
\end{tabular}




\begin{tabular}{|c|c|c|c|c|c|c|c|c|c|c|c|c|}
\hline $44-2$ & $\mathrm{AhbC}$ & -31 & 0.2 & 1.2 & 4.3 & 38.2 & 44 & 45.8 & 8.3 & 0.5 & 55 & 1.4 \\
\hline $44-3$ & CAhb & -45 & 0.5 & 2.4 & 5.9 & 44.6 & 53 & 39.3 & 5.2 & 0.3 & 45 & 1.7 \\
\hline $44-4$ & AhbC & -76 & 0.0 & 0.6 & 2.7 & 38.0 & 41 & 49.4 & 7.2 & 0.7 & 57 & 1.3 \\
\hline $45-1$ & $\mathrm{Ah}$ & -6 & 1.1 & 12.5 & 10.3 & 30.5 & 54 & 34.2 & 4.9 & 1.2 & 40 & 5.3 \\
\hline $45-2$ & CAh & -14 & 0.1 & 0.4 & 4.5 & 37.7 & 43 & 42.8 & 7.9 & 2.0 & 53 & 4.6 \\
\hline $45-3$ & $2 \mathrm{AhbC}$ & -45 & 0.0 & 0.4 & 4.3 & 42.0 & 47 & 42.7 & 5.9 & 2.3 & 51 & 2.5 \\
\hline $45-4$ & $2 \mathrm{C}$ & $-70+$ & 2.9 & 7.0 & 5.5 & 29.3 & 45 & 41.5 & 10.1 & 1.6 & 53 & 2.2 \\
\hline $46-1$ & $\mathrm{Ah}$ & -12 & 0.5 & 4.8 & 3.9 & 34.3 & 44 & 44.6 & 8.3 & 1.7 & 55 & 1.8 \\
\hline $46-2$ & $\mathrm{C}$ & -24 & 0.0 & 0.4 & 4.4 & 39.8 & 45 & 45.8 & 7.9 & 0.7 & 54 & 1.0 \\
\hline $46-3$ & $\mathrm{AhbC}$ & -30 & 0.0 & 0.3 & 4.9 & 44.2 & 49 & 41.4 & 7.4 & 0.4 & 49 & 1.5 \\
\hline $46-4$ & $\mathrm{C}$ & -52 & 1.7 & 5.8 & 3.0 & 31.7 & 42 & 47.1 & 10.0 & 0.0 & 57 & 0.8 \\
\hline $46-5$ & $2 \mathrm{C}$ & -95 & 28.0 & 64.1 & 5.3 & 0.9 & 98 & 0.2 & 1.3 & 0.9 & 2 & 0.1 \\
\hline $46-6$ & $3 \mathrm{C}$ & $-100+$ & 0.2 & 54.9 & 29.8 & 12.0 & 97 & 2.5 & 0.2 & 0.1 & 3 & 0.2 \\
\hline $47-1$ & $\mathrm{AhC}$ & -10 & 0.3 & 14.7 & 16.1 & 38.9 & 70 & 26.5 & 1.6 & 0.3 & 28 & 2.1 \\
\hline $47-2$ & Ahb & -20 & 0.1 & 0.7 & 2.4 & 30.7 & 34 & 49.5 & 9.1 & 1.8 & 60 & 5.6 \\
\hline $47-3$ & CAhb & -70 & 0.1 & 0.7 & 2.3 & 30.5 & 34 & 53.8 & 8.5 & 1.4 & 64 & 2.8 \\
\hline $47-4$ & $\mathrm{C}$ & $-95+$ & 0.1 & 0.2 & 2.4 & 31.3 & 34 & 52.9 & 9.0 & 1.3 & 63 & 2.9 \\
\hline $48-1$ & $\mathrm{AhC1}$ & -15 & 0.0 & 0.4 & 3.5 & 37.7 & 42 & 44.9 & 8.8 & 1.1 & 55 & 3.6 \\
\hline $48-2$ & $\mathrm{AhC2}$ & -30 & 0.0 & 0.3 & 3.7 & 38.4 & 42 & 46.1 & 8.3 & 1.0 & 55 & 2.2 \\
\hline $48-3$ & $\mathrm{C} 1$ & -45 & 2.5 & 0.1 & 1.5 & 31.2 & 35 & 53.9 & 9.2 & 1.5 & 65 & 0.1 \\
\hline 48-4 & $\mathrm{C} 2$ & -65 & 0.5 & 1.0 & 2.1 & 21.6 & 25 & 57.0 & 14.6 & 2.2 & 74 & 1.0 \\
\hline D0-a & $\mathrm{C} /$ dune & -20 & 16.3 & 35.5 & 18.8 & 17.0 & 88 & 9.0 & 1.4 & 0.5 & 11 & 1.6 \\
\hline D0-b & $\mathrm{C} /$ dune & -44 & 4.1 & 23.3 & 20.8 & 33.3 & 81 & 15.1 & 1.0 & 0.1 & 16 & 2.5 \\
\hline D0-c & $\mathrm{C} /$ dune & -47 & 16.9 & 46.8 & 8.8 & 13.4 & 86 & 9.3 & 2.0 & 0.7 & 12 & 2.2 \\
\hline D0-d & $2 \mathrm{Ahb} 1$ & -57 & 17.2 & 20.8 & 6.0 & 27.1 & 71 & 22.4 & 2.9 & 1.0 & 26 & 2.7 \\
\hline D0-e & $2 \mathrm{Ahb} 2$ & $58+$ & 13.2 & 19.8 & 6.6 & 26.3 & 66 & 26.4 & 4.0 & 0.4 & 31 & 3.3 \\
\hline D1-a & $\mathrm{C} /$ dune & -4 & 36.1 & 25.5 & 10.6 & 17.2 & 89 & 7.7 & 1.3 & 0.1 & 9 & 1.8 \\
\hline D1-b & $\mathrm{C} /$ dune & -7 & 44.7 & 26.3 & 9.1 & 12.0 & 92 & 6.3 & 0.4 & 0.1 & 7 & 1.0 \\
\hline D1-c & $\mathrm{C} /$ dune & -10 & 4.6 & 22.8 & 12.9 & 35.9 & 76 & 18.7 & 0.1 & 0.3 & 19 & 4.7 \\
\hline D1-d & $\mathrm{C} /$ dune & $55-65$ & 8.8 & 22.4 & 11.1 & 29.4 & 72 & 25.3 & 0.7 & 0.2 & 26 & 2.1 \\
\hline D1-e & $2 \mathrm{Ahb} 1$ & $65-67$ & 4.8 & 9.7 & 6.8 & 42.5 & 64 & 29.2 & 3.1 & 0.4 & 33 & 3.7 \\
\hline
\end{tabular}




\begin{tabular}{|c|c|c|c|c|c|c|c|c|c|c|c|c|}
\hline D1-f & $2 \mathrm{Ahb} 2$ & -98 & 0.6 & 3.1 & 9.7 & 45.8 & 59 & 35.0 & 2.9 & 0.2 & 38 & 2.6 \\
\hline D1-g & $2 \mathrm{Ahb} 3$ & $99+$ & 0.2 & 0.9 & 4.9 & 46.0 & 52 & 37.9 & 4.4 & 1.0 & 43 & 4.6 \\
\hline D2-a & $\mathrm{C} /$ dune & -13 & 6.8 & 28.9 & 20.7 & 27.1 & 84 & 13.6 & 1.3 & 0.1 & 15 & 1.3 \\
\hline D2-b & $\mathrm{C} /$ dune & -28 & 25.0 & 30.8 & 13.4 & 18.7 & 88 & 9.8 & 1.1 & 0.1 & 11 & 1.1 \\
\hline D2-c & $\mathrm{C} /$ dune & $57-59$ & 7.1 & 27.1 & 30.1 & 29.1 & 94 & 4.7 & 0.1 & 0.3 & 5 & 1.4 \\
\hline D2-d & $2 \mathrm{C}$ & $61-71$ & 1.0 & 4.2 & 5.7 & 41.1 & 52 & 39.2 & 5.1 & 0.9 & 45 & 2.7 \\
\hline D2-e & $3 \mathrm{AhC}$ & -81 & 0.1 & 1.0 & 5.5 & 44.6 & 51 & 41.7 & 4.1 & 0.7 & 46 & 2.3 \\
\hline D2-f & 4Ahb1 & -96 & 0.0 & 0.6 & 4.2 & 41.4 & 46 & 43.0 & 5.1 & 0.8 & 49 & 4.8 \\
\hline D2-g & 4Ahb2 & -112 & 0.0 & 0.5 & 4.9 & 47.7 & 53 & 39.0 & 4.3 & 0.8 & 44 & 2.8 \\
\hline D2-h & 4Ahb3 & $112+$ & 0.0 & 0.4 & 1.5 & 31.1 & 33 & 56.1 & 5.7 & 2.0 & 64 & 3.1 \\
\hline D3-a & $\mathrm{C} /$ dune & -12 & 23.3 & 41.6 & 11.3 & 12.0 & 88 & 9.9 & 0.7 & 0.4 & 11 & 0.9 \\
\hline D3-b & $2 \mathrm{C}$ & -17 & 0.9 & 2.2 & 3.9 & 34.5 & 41 & 46.6 & 8.0 & 0.8 & 55 & 3.1 \\
\hline D3-c & $3 \mathrm{AhC}$ & -22 & 0.1 & 0.6 & 4.3 & 40.6 & 45 & 42.9 & 7.3 & 0.7 & 51 & 3.7 \\
\hline D3-d & 4Ahb1 & -32 & 0.5 & 0.9 & 4.9 & 42.4 & 49 & 40.0 & 7.5 & 0.8 & 48 & 3.0 \\
\hline D3-e & 4Ahb2 & -35 & 0.0 & 0.2 & 3.2 & 43.6 & 47 & 45.3 & 6.5 & 0.8 & 53 & 0.3 \\
\hline D3-f & 4Ahb3 & -39 & 2.2 & 3.3 & 2.9 & 26.4 & 35 & 50.8 & 11.8 & 1.5 & 64 & 1.1 \\
\hline D3-g & 4Ahb4 & $40+$ & 18.1 & 27.6 & 12.8 & 15.5 & 74 & 14.0 & 7.3 & 2.2 & 24 & 2.5 \\
\hline
\end{tabular}




\begin{tabular}{|c|c|c|c|c|c|c|}
\hline No. & Site description & Aspect & Inclination $\left[^{\circ}\right]$ & Width $[\mathrm{m}]$ & Length $[\mathrm{m}]$ & Depth $[\mathrm{cm}]$ \\
\hline 1 & Slope & SE & 13 & 18 & $10-14$ & 65 \\
\hline 2 & Crest, bowl-shaped & SE & 9 & 1.80 & 3 & 45 \\
\hline 3 & Upper slope range, strongly wind exposed & E-SE & 11 & 4 & 8 & 50 \\
\hline 4 & Steep slope, strongly wind exposed & $\mathrm{S}$ & 11 & $2.50-25$ & $3-10$ & 70 \\
\hline 5 & Steep slope, vegetated bowl, more wind protected & $\mathrm{S}$ & 19 & 2.50 & 7.50 & 64 \\
\hline 6 & Almost hilltop, partly vegetated & $\mathrm{S}$ & 8 & 3.10 & 7.20 & 52 \\
\hline 7 & Moraine & S-SE & 9 & 6 & 7 & 32 \\
\hline 8 & Bouldery & SE & 9 & 36 & 24 & 50 \\
\hline 9 & Moraine & S-SE & 8 & 27 & 23 & 35 \\
\hline 10 & Moraine, aeolian blow-outs in luv and lee & E-SE & 7 & 7 & 6 & 43 \\
\hline 11 & Moraine & SE & 12 & 20 & 200 & 40 \\
\hline 12 & Moraine in dunefield, barren of vegetation & SE & 13 & 4 & 8.30 & 70 \\
\hline 13 & Moraine in dunefield & S-SE & 8 & 25 & 75 & 80 \\
\hline 14 & Moraine in dunefield & S-SE & 13 & 6.10 & 10.60 & 95 \\
\hline 15 & Moraine in dunefield, bouldery & SE & 1 & 25 & 190 & 60 \\
\hline 16 & Moraine in dunefield & SE & 7 & $8-15$ & 20 & 55 \\
\hline
\end{tabular}

